Max-Planck-Institut für demografische Forschung

Max Planck Institute for Demographic Research

Konrad-Zuse-Strasse 1 - D-18057 Rostock - GERMANY

Tel +49 (0) 3812081 - 0; Fax +49 (0) 3812081 - 202;

http://www.demogr.mpg.de

MPIDR WORKING PAPER WP 2013-016

NOVEMBER 2013

\title{
Does waiting pay off? \\ The effect of partnership duration \\ prior to household formation \\ on union stability
}

Christine Schnor (schnor@demogr.mpg.de)

This working paper has been approved for release by: Michaela Kreyenfeld (kreyenfeld@demogr.mpg.de),

Deputy Head of the Laboratory of Economic and Social Demography.

(C) Copyright is held by the authors.

Working papers of the Max Planck Institute for Demographic Research receive only limited review. Views or opinions expressed in working papers are attributable to the authors and do not necessarily reflect those of the Institute. 


\section{Does waiting pay off? - The effect of partnership duration prior to household formation on union stability}

Christine Schnor (schnor@demogr.mpg.de) 


\begin{abstract}
This article investigates how the length of the non-residential partnership phase, which is known as LAT (living apart together), relates to separation behavior. There is a large body of literature on the effects of cohabiting prior to marriage on union stability. However, relatively few studies have examined how the LAT period before moving in together influences separation risks. This is surprising, as this study has found that 90 percent of the unions were preceded by an LAT period. On the one hand, we might expect to find that a short LAT period has a negative influence on union stability, because the partners have relatively little information about each other, and mismatches are therefore possible. It is, however, also conceivable that a short LAT period prior to moving in together is indicative of the couple's commitment to the union. Data for the empirical analyses came from the German Family Panel. The dataset includes 8,230 residential non-marital and marital unions of 2,899 men and 3,866 women born in 1971-1973 and in 1981-1983. Multilevel piecewise constant survival models were estimated to assess the influence of the length of the LAT (living apart together) period on stability. The results reveal that union stability is positively related to the length of the LAT phase. However, the separation rates of unions without a prior LAT period are also low. The LAT stage has a similar impact on cohabitations and on marriages. The findings suggest that the LAT period is a significant phase in the partnership which enables couples to acquire information about the quality of the partnership.
\end{abstract}

Keywords: union stability, separation, living apart together, non-residential partnership, household formation, cohabitation, marriage, German Family Panel 


\section{Introduction}

Over the past few decades, new forms of living arrangements within partnerships have emerged in many western countries. Partnerships can be defined as emotional relationships in which the partners may or may not be married, and may or may not share a residence. The term "union" usually refers only to couples who live together, in cohabitation or in marriage. Couples who live in separate households represent a distinct partnership type referred to as "living apart together" (LAT) (Duncan \& Phillips 2011; Levin \& Trost 1999). The proportion of partners living in a non-marital union has increased in recent years, and cohabitation has replaced marriage as the leading choice for a first union (Sobotka \& Toulemon 2008). In addition to cohabitation, non-residential partnerships have become widespread, at least in western Europe (Duncan \& Phillips 2011; Régnier-Loilier et al. 2009). This trend has been interpreted by some scholars as representing an expression of individualization, which may imply less commitment to others (Lesthaeghe \& Surkyn 1988; Poortman \& Liefbroer 2010). Delayed union formation, the increase in non-traditional living arrangements, and rising rates of separation are aspects of the broader societal change which has been called the Second Demographic Transition (Lesthaeghe \& Meekers 1986; Lesthaeghe 2010; van de Kaa 1987). The trend toward extended periods of LAT has caused some observers to raise concerns that partnerships are becoming more fragile.

However, LAT often functions as a temporary arrangement preceding household formation (Ermisch \& Siedler 2009): couples frequently have separate homes at the start of the partnership, and there is a considerable flow from non-residential partnerships to cohabitation and marriage (Castro-Martin et al. 2008; Ermisch \& Siedler 2009; Régnier-Loilier et al. 2009). How well the partners knew each other at the time of household formation and how much time the partners 
needed before deciding to move in together may have critical effects on the stability of the union. According to the theoretical considerations of Becker et al. (1977) and Oppenheimer (1988), a relationship is more likely to be stable if the partners have solid information about each other's personal characteristics. A short LAT episode should be related to a high degree of uncertainty about the partner's attributes at the time the household is formed, which might decrease the prospects of union success. Other scholars have, however, suggested that there is a negative relationship between non-residential partnership length and subsequent union stability (Thibaut \& Kelley 1958). The process of developing intimate relationships requires the partners to be motivated to invest in the partnership (Brown 2003). A hesitation to invest may indicate that the partners anticipate a high risk of disruption.

This study follows up on the view of the LAT partnership as a stepping stone to a more committed residential partnership, and focuses on the separation behavior of couples who had just started living together. The article investigates the risk of separation among married and unmarried couples in a residential union. Married and cohabiting couples have a lot in common: couples who live together tend to develop similar daily routines (Levin 2004; Jalovaara 2013; Rindfuss \& VandenHeuvel 1990). There is empirical evidence that several determinants of union dissolution have similar effects on both union forms (Jalovaara 2013). People in residential unions profit from being able to pool their resources and from the economies of scale that come from sharing a home (Oppenheimer 1988). These advantages are forfeited if the partners decide to dissolve the partnership (Rhoades et al. 2012). To avoid the high costs of separation, it is essential to form a residential union with good prospects for stability. A large number of studies have focused on premarital cohabitation as a stepping stone to marriage, and have examined the role of cohabitation in marital stability (e.g. Bracher et a. 1993; Jalovaara 2013, Thomson \& Colella 1992, Lillard et al. 1995, Berrington \& Diamond 1999). However, previous studies rarely accounted for the non-residential partnership 
period prior to household formation, because appropriate data for studying this phase of the partnership were not widely available. The findings of most surveys are not suitable for addressing this research question because they do not include information on the non-residential partnership period. In this paper, the German Family Panel is used, which offers detailed partnership histories, including starting and ending dates of LAT episodes. German non-residential partnerships do not appear to be exceptional with regard to their prevalence and duration, as a British-German comparison revealed (Ermisch \& Siedler 2009). Thus, although this study refers to a single country, the results may be transferable to other settings. Retrospective partnership histories of German women and men born in 1971-1973 or in 1981-1983 are used. These data therefore allow to study residential unions and partnership dynamics at early adult ages, but not at later stages of the life course. The analytical sample consists of 8,230 partnerships.

Our goal in this paper is to reduce the research gap on the non-residential partnership period. It is the first study that seeks to explore how the LAT period influences the risk of separation among residential marital and non-marital partnerships.

\section{Background}

\subsection{Theoretical considerations and hypotheses}

In the economic theory of the family (Becker 1991; Becker et al. 1977), household formation is considered essential because it enables the production of commodities. Although the focus of this theory is on marriage, its findings can be applied to all unions, since household and marriage formation are seen as coinciding. Oppenheimer's theory of marriage timing (Oppenheimer 1988) also concentrates on marriage, and considers cohabitation as a potential precursor to marriage. 
According to these theoretical concepts, the key to union stability is for the partners in a couple to have information about each other's characteristics. Participants in the partner market have limited information about the utility they can expect from potential mates because they have only limited information about their traits (e.g., honesty, reliability, personality). People date and try to gather information about the characteristics of each prospective partner. A good match is the result of a selection process and of adaptive socialization during the courtship process (Oppenheimer 1988). Because each of the partners has incomplete information about the other at the start of the partnership, suboptimal matches are possible, and the disruption risk is high. This implies that immediately after partnership formation, the couple is cautious about investing due to uncertainty. As a consequence, couples who take the time to collect information about the potential domestic partner should have much better prospects of union success than couples who move in together quickly. Those partners who discover that they are not well matched are less likely to form a household, and will presumably end the partnership (Lillard et al. 1995). Thus, high separation rates lead to a weeding-out of non-compatible couples. With increasing partnership duration, the partners who continue living apart together not only get to know each other better; they become increasingly positively selected. This process should enhance the stability of the union after household formation. Based on these considerations, the following main hypothesis can be derived: the longer the LAT period, the more stable the union is likely to be after household formation.

According to exchange theory (Thibaut \& Kelley 1959: 12ff), the partners in a couple aim to broaden their exchange and deepen their investments. Relationship stability is determined by the intensity of successful interactions. The rewards and costs of these interactions are evaluated by the partners, and lead them to decide to invest further through more interactions or to end the relationship. The rewards of the interactions are compared with the potential rewards from the available alternative partners. The partners who rapidly make investments may be strongly 
convinced that the relationship will last, while the partners who hesitate to invest may have doubts about whether the stability of the relationship, and may continue to consider alternative partners (Brown 2003). Household formation is an investment that seems to be practically motivated by the transaction costs of interactions, which increase if interactions are extended, such as through more time spent together engaging in leisure activities, cooking, sleeping, etc. If the interaction density exceeds a critical mass, a joint household has strong interaction and specialization benefits, because the partners share time, money, and household tasks. However, a certain loss of freedom and independence contributes to the costs of household formation (Rhoades et al. 2010, 2012). The nonresidential partnership period can be regarded as a step in the courtship process. The longer the relationship persists without the partners moving in together, the greater the perceived union instability might be, as the intention to co-reside remains unrealized. For partners who are together for a long period of time prior to household formation, the costs of forming a joint household might outweigh the potential rewards for longer than they do for partners who move in together quickly. This situation might arise because one or both of the partners has strongly individualistic attitudes, or for practical reasons, such when the partners are unable to find jobs in the same location (Carmichael 1995). On the other hand, in some cases the rewards of household formation may be lower because, for example, the couple does not share daily routines. These factors may be associated with a decrease in the benefits of forming a joint household even after the couple move in together, and may therefore threaten union stability. A long partnership duration before household formation may further indicate that the interaction density between the partners had not been increasing. However, interaction density seems to be essential for union stability. If the interaction density continues to grow slowly after household formation for a couple who took a long time to move in together, it is likely that their union stability will be lower than that of a couple who started to co-reside shortly after the partnership was formed. As a consequence, the competing 
research hypothesis is that the length of the partnership before the household was formed negatively affects union stability.

So far, I have considered the potential effects of the LAT period on the stability of residential unions without further differentiating by union characteristics. However, it needs to be investigated how the LAT period in relation with the parental status and the marital status affects dissolution risks. In previous studies, children were found to stabilize partnerships, especially when the children were young (Guzzo 2009; Jalovaara 2013; Wu 1995). A closer look at the children's characteristics suggests, however, that the presence of children from previous partners, as well as of children born before household formation, might increase the risk of partnership break-up (Liu 2002; Teachman et al. 1991). The conception of a child within a living apart together partnership might indicate that the pregnancy was unplanned. Following the argumentation of the main hypothesis, the parents-to-be might not have had enough time to evaluate the partners characteristics, which should then result in a elevated risk of union disruption relative to that of a couple who conceived a child while coresiding. Following the competing hypothesis, on the other hand, the joint decision to form a family and a household might indicate that the couple are strongly committed and trust that the partnership will continue. Thus, the conception of a child prior to household formation might have no or even a positive effect on union stability compared to a conception after the household is formed.

To the extent that a short LAT period negatively affects union stability, there are two reasons why this effect might be weaker if the couple are married than if they are not. First, married couples should be more committed to the partnership, because they have entered into a formal arrangement that increases the rewards they can expect from the partnership and the costs of separation (Blossfeld et al. 1999; Le Bourdais et al. 2000; Perelli-Harris \& Sánchez Gassen 2012). Because of this commitment, they may be less willing than non-married couples to end an unsatisfactory 
relationship and be more willing to make an effort to improve the quality of the relationship. The second reason is related to the positive selection into marriage. The period of living apart together does not necessarily directly precede marriage; the couple may have started to live together and then decided to get married. In this case, partnerships with short LAT periods likely to be sorted out prior to marriage due to their high risk of separation.

\subsection{Previous empirical findings}

There is still very limited knowledge about how the partnership phase between dating and living together influences union stability. Only a few studies on marital stability have examined the LAT period as a potential determinant of marital stability. The research that exists has shown that having a long relationship prior to household formation reduces the risk of a marital break-up (Brüderl et al. 1999; Brüderl \& Kalter 2001; Engelhardt 2002; Murphy 1985; Niephaus 1999). Unfortunately, these studies did not analyze whether this effect differed between direct marriages and marriages preceded by cohabitation.

Moreover, even these studies did not consider the LAT period as an integral part of the partnership dynamics that are relevant for the analysis of union stability. This may be because the periods of living apart together were of minor importance in past decades, as many couples did not move in together due to external constraints. However, LAT is now largely recognized and accepted as a partnership form. Couples may live apart not just because they are forced to do so by circumstances, but because they have chosen not to live together, even though it would be possible for them to do so (Duncan \& Phillips 2011). Although it is a common stage on the path to cohabitation and marriage, the non-residential partnership phase was often ignored in social surveys (Castro-Martin et 
al. 2008), and, as a consequence, appropriate data (in terms of large representative samples with detailed date information) were not available. Most surveys only provide information about the household formation date, which prior research has taken as the partnership start point (Manning 2001; Raley 2001). However, it is not that simple: the time spent in a partnership is not to be equated with the time spent in a residential non-marital or marital union (Carmichael 1995).

Related literature on the effect of cohabitation before marriage can shed some more light on my research goal. Similar to LAT, premarital cohabitation is a precursor to a more committed partnership arrangement. It is possible that the effects on separation of the length of these preceding partnership phases are alike. However, the premarital cohabitation phase differs from the LAT phase in that it is not experienced by all of the couples, whereas the LAT phase is a standard stage in the partnership life course. Referring to the decision to marry directly or after cohabitation, a large number of studies have analyzed whether premarital cohabitation affected the risk of marital dissolution (e.g., Brien et al. 2006; Brüderl et al. 1997; Kulu \& Boyle 2009; Lillard et al. 1995; Svarer 2004). Comparatively few studies have considered how the length of premarital cohabitation relates to divorce risks. Several studies have shown that the risk of divorce decreases with the amount of time the couple cohabited prior to marriage, provided the cohabitation period did not exceed two years (Berrington \& Diamond 1999; Bracher et al. 1993; Hoem 1989; Jalovaara 2013; Klijzing 1992; Murphy 1985). Couples who cohabited for longer periods had less marital stability. Other studies even found that the risk of marital breakdown is positively related to cohabitation length (Teachman \& Polonko 1992; Thomson \& Colella 1992). While the positive effect of cohabitation duration on marriage dissolution is explained by the lower degree of commitment of couples who cohabit long term, the negative effect of the cohabitation duration on separation is commonly attributed to the testing character of this partnership phase. 
A number of studies have examined LAT partnerships in Germany, and have described the transition from LAT to co-residence or separation. ${ }^{1}$ A study on German marriage cohorts formed between 1999 and 2005 showed that it took couples an average of 2.4 years to move in together (50 percent formed a household within the first year of the partnership) (Schneider \& Rüger 2008). Survival estimates based on GSOEP data revealed that 80 percent of the non-residential partnership episodes lasted more than one year, but only 13 percent were intact after 10 years (Ermisch \& Siedler 2009). Around 55 percent of these German LAT partnerships were transformed into residential unions, while 45 percent were dissolved before household formation (Ermisch \& Siedler 2009). Non-residential partnerships mainly occurred among young people: the earlier the partnership was formed in the life course of the couple, the longer the non-residential period lasted (Schneider \& Rüger 2008). At around the age of 25, the LAT partnership was often transformed into a residential union (Asendorpf 2008; Ermisch \& Siedler 2009; Régnier-Loillier et al. 2009).

\section{Methodology}

\subsection{Sample}

The data were drawn from the German Family Panel (pairfam Release 3.1), a nationwide random sample of 13,891 German adults born in 1971-1973, 1981-1983, and 1991-1993; including an oversample of eastern German respondents (DemoDiff 2.0) (pairfam: Huinink et al. 2010, Nauck et

\footnotetext{
${ }^{1}$ These studies referred to data which included information on the LAT episode, but they had had certain drawbacks: e.g., that the date information was collected on a yearly basis, that the study did not account for partner changes (e.g., Ermisch \& Siedler 2009), or that study only considered the partnership histories of marital couples (Schneider \& Rüger 2008).
} 
al. 2012; DemoDiff: Kreyenfeld et al. 2011, 2013a, 2013b). ${ }^{2}$ A design weight was used in the descriptive analyses that accounted for the under-/overrepresentation of the birth cohorts in the gross sample and the oversampling of eastern Germans. ${ }^{3}$ Personal standardized interviews were conducted annually from 2008 to 2012. In the first interview, retrospective partnership histories on monthly basis were collected. The partnership information was updated with each subsequent wave. I made use of a ready-to-use event history dataset that incorporates all of the relevant partnership and fertility information (Schnor \& Bastin, forthcoming). The analyses included the retrospective partnership histories of both the male and the female respondents. A drawback of the data was that information on the individual characteristics of both partners was not available in cases in which the partnership was dissolved prior to the first interview. This implies that individual information for only one of the partners was available, and that there were no couple data. Thus, I decided to conduct separate analyses for the male and the female respondents. ${ }^{4}$ Some variables may be expected to affect the separation risks of men and women differently, such as employment status (Jalovaara 2013). Beyond that, some variables might have different meanings. For example, because men are on average older than women at the time of partnership formation, age may play a different role among women than among men. Being age 23 when the household was formed might be rather standard among women, while it might signify an early event in the private life course of men.

The analysis was limited to residential partnership episodes of women and men born in 1971-1973 or in 1981-1983. Members of the youngest cohort (born 1991-1993) were not considered because most (95 percent) had not experienced household formation at the time of the most recent

\footnotetext{
2 The German Family Panel is coordinated by Josef Brüderl, Johannes Huinink, Bernhard Nauck, and Sabine Walper. It is funded as a long-term project by the German Research Foundation (DFG).

${ }^{3}$ In detail, I used the following weights (Kreyenfeld et al. 2013): birth cohorts 1971-73, eastern Germany (including East Berlin): 0.395; birth cohorts 1981-83, eastern Germany (including east Berlin): 0.414; birth cohorts 1971-73, western Germany: 1.098; birth cohorts 1981-83, western Germany: 0.961.

4 In a joint model I would have to interact gender with all of the other covariates in order to exclude the possibility that the influence on separation differs between men and women.
} 
interview. Partnerships formed before the $14^{\text {th }}$ birthday of the respondent were excluded because the pairfam questionnaire only asked about partnership episodes starting after that date. I also excluded partnerships which started after household formation, partnerships with cohabitation breaks, partnerships in which residential episodes with different partners overlapped, partnerships which ended with the partner's death, as well as partnerships for which the partnership duration prior to household formation exceeded 10 years. Unions in which the joint household was dissolved while the partnership remained stable were dropped, because this was more related to job mobility than to union stability. In addition, partnerships were omitted if information on the partnership or fertility biography or the country of birth was missing. Same-sex residential partnerships were excluded as well, because there were only a few cases in the sample. ${ }^{5}$ The remaining sample consists of 6,536 first residential unions and 1,694 higher order residential unions of 2,899 men and 3,866 women.

\subsection{Method and operationalization}

My aim was to model the union stability of residential unions, with a focus on the impact of the partnership duration before the partners moved in together. Therefore, the period observed and the event of interest had to be defined. The data offer information on the date of household dissolution (= union dissolution), as well as on the date of partnership dissolution (= separation), as partnership histories beyond residential union episodes were collected. Household dissolution was defined as the dependent variable, because the study focused on residential unions; thus, the main interest lay in the length of the residential episode. In most cases, household and partnership dissolution were close together in time, and occurred within a time frame of one year, as can be seen from Figure 4

\footnotetext{
${ }^{5}$ There were 77 same-sex unions in the sample, which represented less than one percent of the analytical sample.
} 
(Appendix). A multilevel piecewise constant survival model was used to estimate the relative risks of household dissolution (Gutierrez 2002). The observation time started with household formation. The observation was censored with the time of the latest interview and eight years after household formation to account for the young age structure of the respondents. The household episode was split into yearly intervals within the first three years, and again after five years, which resulted in five baseline categories (0-1 years, 1-2 years, 2-3 years, 3-5 years, 5-8 years). There were data on the household dissolutions of one or more unions per respondent. This implied a multilevel structure of the data: to account for within-respondent heterogeneity, a random intercept for each respondent was added to the model.

The partnership duration prior to household formation was considered as an independent timeconstant variable. The information on the partnership formation date was based on self-reported partnership histories. It should be taken into account that, in contrast to the marriage date, the partnership formation date is often less clearly definable (Duncan \& Phillips 2011; Régnier-Loillier et al. 2009). Partnership formation may be perceived as a period rather than as a date, and its definition can be related to the first kiss, the first night spent together, the first declaration of love, or the introduction of the partner to friends/parents. The questionnaire did not specify any criteria, and left the definition up to the respondent. Information was gathered on episodes of partnerships, residential unions, and marriages. With regard to the retrospectivity of the partnership information, it is important to note that the information might have been subject to recall problems (Reimer 2005). The respondents might not have remembered the concrete dates correctly (Dex 1995; Reimer 2005: 35), they might have mixed up the dates. In the case of unions without a prior LAT episode, for example, the household formation date might be remembered as the partnership start date, although the partnership had started some time before. Direct marriages without prior non- 
residential episodes represented a special case. ${ }^{6}$ They might indicate a recall problem, because it seems unlikely that partnership, cohabitation, and marriage formation were commenced simultaneously. However, the definition of the partnership start was left to the respondent, who might have had reasons for saying that the partnership started on the marriage date. Difficulties in recalling past events and periods increase with age (Reimer: 40). In this study, the young age structure of the respondents minimizes the risk of recall bias. Research has shown that men recall retrospective information differently from women, and that the quality of partnership histories tends to be higher when reported by women than when reported by men (Cherlin \& McCarthy 1984; Reimer 2005: 40, 79). This gives another reason for estimating the effect of partnership duration on stability separately for male and female respondents.

Figure 1 shows how the LAT length was distributed in the data. About 10 percent of the partnerships started directly with household formation, and 50 percent of the partnerships formed a household within their first partnership year. Another 20 percent did so within the second union year. The vast majority, or 90 percent, had moved in together within the first five years of the partnership, while only 10 percent reported partnership durations of five to 10 years prior to household formation. The length of the partnership periods reported by the younger birth cohorts (1981-1983) did not differ from those reported by the older birth cohorts (1971-1973). Likewise, the distribution of the variable was found to be identical for male and female respondents.

\footnotetext{
${ }^{6}$ Among all direct marriages, only 9 percent had identical dates of partnership, household and marriage formation.
} 
Total

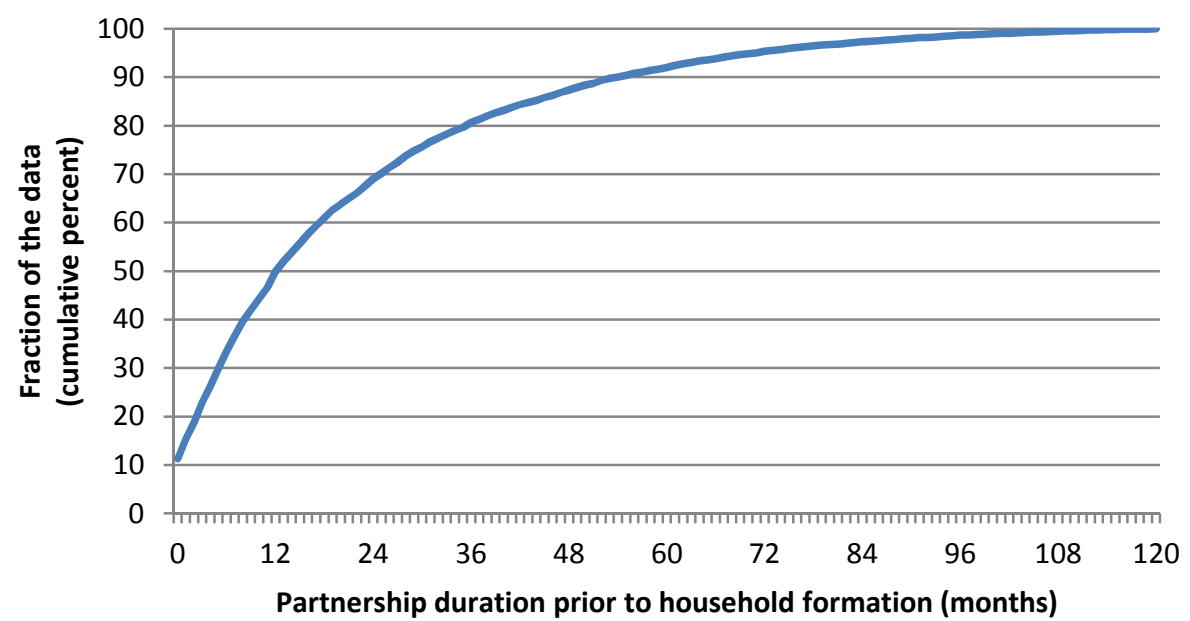

Figure 1: Cumulative percentage of partnership length prior to household formation.

Source: German family panel (pairfam/DemoDiff), Release 3.0 (2011/2012)

Note: Weighted sample

Previous studies accounted for years spent in the LAT with a linear covariate (Brüderl et al. 1999; Brüderl \& Kalter 2001; Engelhardt 2002; Niephaus 1999). As half of the partnerships were transformed into residential unions within the first partnership year, the categorization in yearly intervals might be too rough. I therefore decided against using a metrical (be it linear, squared, or logarithmic) definition. Instead, I constructed a categorical variable in which partnership duration prior to household formation was grouped into terciles according to the distribution in the data. The resulting final categories are " 1 st $t e r c i l e: 1-9$ months," " $2^{\text {nd }}$ tercile: $10-25$ months," and " $3^{\text {rd }}$ tercile: 26 120 months." Those who reported having started their relationship as a residential union were grouped in a separate category. An advantage of taking this approach was that the risk of household dissolution among partnerships with an average partnership duration $\left(\approx 2^{\text {nd }}\right.$ tercile $)$ could be 
compared to that of couples who moved in together relatively early $\left(1^{\text {st }}\right.$ tercile $)$ or late $\left(3^{\text {rd }}\right.$ tercile $)$ in the relationship.

Several control covariates were considered in the multivariate regression models. There was information on the marital status of the partnership. If the marriage occurred prior to household formation, a time-constant category stated that it is a "direct marriage;" two further time-varying categories accounted for the time spent living together while not married and the time spent living together while married after some period of non-marital cohabitation ("converted marriage"). A distinction between direct marriages and converted marriages is made because partners who get married before moving in together often have very traditional attitudes and represent a selected subgroup (Klijzing 1992; Köppen 2011: 235; Liebroer \& Dourleijn 2006). According to Bennett et al. (1988) and Lillard et al. (1995), couples who start their union by getting married are more committed to the institution of marriage than couples who start their union with non-marital cohabitation, and who marry at some later point in time.

The parental status of each union was defined as childless (= no common offspring) or as having common children of a certain age. There might have been a common child present (or underway) at the time of household formation; these cases were defined as having a "pre-union child." Stepchildren were defined as the biological offspring of the respondent or of his partner and a previous partner who lived in the household at the time of household formation.

Several covariates provided information about the partnership history of the respondent. These included the age at which a household was formed, the order of the residential union, and the number of (previous) partners (including the partner with whom the household was formed). The age at the entry into a cohabiting union has been shown to be negatively related to disruption risks, (Berrington \& Diamond 1999, Jalovaara 2013, White 1990). This is because younger people tend to 
be less mature, and they have a greater availability of alternative partners (Becker et al. 1977). First residential unions might have a greater level of stability than higher order unions, because the latter might be formed by individuals who are more prone to separation. In previous studies, the cohabitation order was shown to have no effect on stability, while higher order marriages were found to be less stable than first marriages (Berrington \& Diamond 1999; Manlove et al. 2012; Poortman and Lyngstad 2007; Steele et al. 2006). The number of previous partners can serve as an indicator of an extensive partner search (Becker et al. 1977). Having had prior partnerships may indicate that the current partner has been tested and has been shown to be suitable as a residential partner (in contrast to prior candidates), which may be related to increased union stability. On the other hand, individuals with a previous partnership may have lower levels of union stability because may be more prone to separation than people who are partnered for the first time. There is also information about whether the respondent lived with his or her parents at the time the partnership was formed. Living in the parental home might suggest that these individuals were less mature, which would be associated with a higher risk of union break-up (Becker et al. 1977).

The models further included personal information on the educational, religious, and family backgrounds of the respondents, and on their economic activities. The levels of school education were broken down into three categories: low (no certificate or lower secondary education), middle (secondary education), and high (high school diploma). Missing information on school education was ascribed to a separate category. Empirical studies have shown that more highly educated individuals have better partnership prospects than their less educated counterparts (Brüderl et al. 1997; Jalovaara 2013; Berrington \& Diamond 1999). Education can increase household stability, because highly educated individuals are expected to make better partner choices and to have fewer communication problems (Amato 1996). A further variable showed whether the male or female respondent was enrolled in education (including tertiary education) at the time the partnership was 
formed. This may be related to a lower degree of union stability because the person is not yet settled and may be less mature and forward-looking with regard to partner choice (Becker et al. 1977).

Church membership provides information about the person's religious background. Respondents who were neither Catholic nor Protestant, but who belonged to another religious community were grouped in a single category. A number of studies have shown that Catholics marry later and have a lower risk of union dissolution than non-Catholics (Hoem \& Hoem 1992; Lehrer 2004; Lillard et al. 1995; Oláh 2001; Teachman 2002). The costs of union dissolution are particularly high in Catholicism, because the church prohibits separation after entry into marriage. The higher costs associated with making a mistake suggests that Catholics may engage in a more intensive partner search and take more time to form a household than non-Catholics (Lehrer 2004).

Individuals who experienced parental separation have been shown to be more likely to dissolve their unions (Lyngstad \& Jalovaara 2010). As there was information on whether the respondent lived with both biological parents until his or her 18th birthday, this was taken as an indicator of whether a parental separation occurred during the respondent's childhood or adolescence. A time-varying variable provided information on the current employment status. Based on the self-assessed employment history, I distinguished between employed and non-employed episodes. Information on living with both biological parents and on employment status was not available for all of the respondents because these data were gathered in the second and the third waves of the German family panel, respectively. A separate category indicated missing information, which applied if the respondent did not reply or did not participate in the respective waves. 


\section{Results}

\subsection{Descriptive results}

In Figure 2, Kaplan-Meier survival estimates show the probability of union survival within the period observed. The unions formed in the early months of the partnership ( $1^{\text {st }}$ tercile) had the lowest survival probabilities: only around 63 percent of the unions were intact eight years after household formation. In contrast, the residential unions with a prior non-residential period of 10 to 25 months ( $2^{\text {nd }}$ tercile) had somewhat higher survival probabilities, as 67 percent had not experienced household dissolution. Among those who had directly formed a household, a similar proportion (68 percent) were still together. Among those couples who had spent a relatively long period living apart before they moved in together $\left(3^{\mathrm{rd}}\right.$ tercile), the probability of union survival was highest: 76 percent were still living together at the end of the observation period.

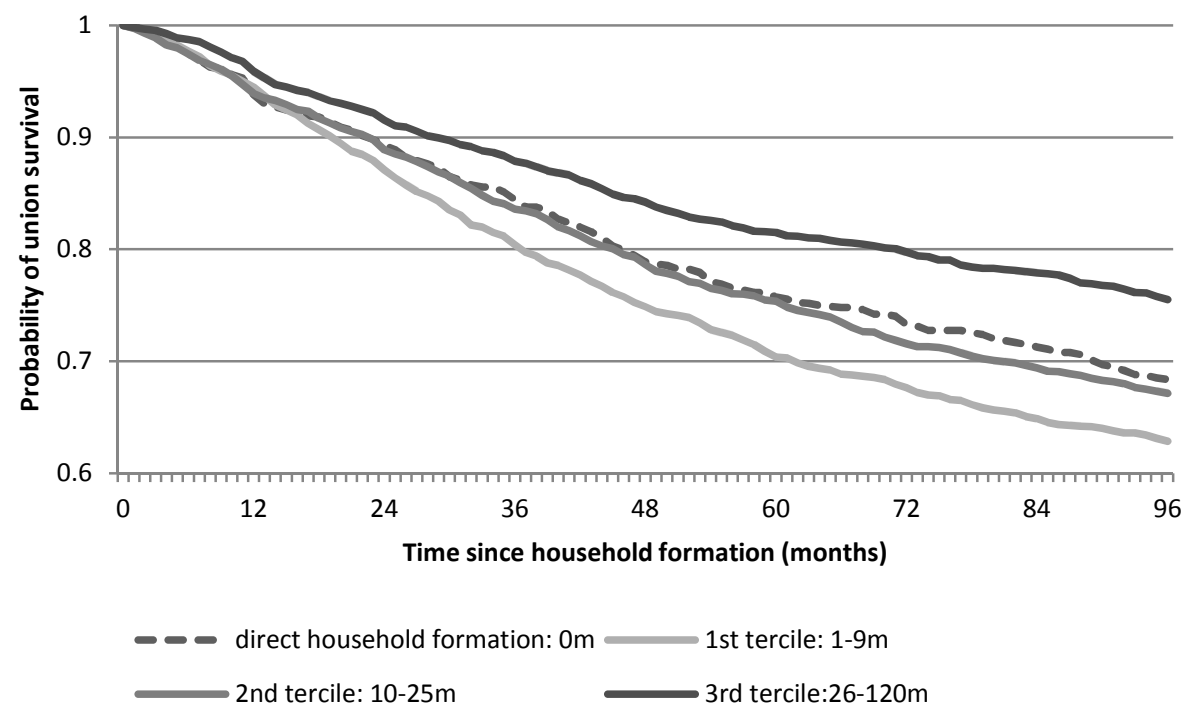


Figure 2: Kaplan-Meier survival estimates. Household stability by partnership duration prior to household formation (in terciles).

Source: German family panel (pairfam/DemoDiff), Release 3.0 (2011/2012)

Note: Weighted sample

\section{Sample composition}

The sample composition by gender and duration of the LAT phase is shown in Table 1. It reveals whether the respondents with a short LAT period prior to household formation differed in their characteristics from the respondents who waited a substantial amount of time before moving in with their partner.

The unions with different prior LAT periods spent similar amounts of time living together while unmarried. Direct marriages were most prevalent among the couples who had no prior partnership history. During the observation period, half of the time was spent childless. The unions with different prior partnership periods did not vary substantially in terms of the amount of time they spent with children at different ages. Stepchildren were more predominant in the households with a short prior partnership duration, as reported by the female respondents. According to Table 1, several of the couples conceived a common child prior to household formation. These pre-union children were most common among the unions with a prior LAT length of 10 to 25 months $\left(2^{\text {nd }}\right.$ tercile). However, the male respondents in unions with a long LAT period ( $3^{\text {rd }}$ tercile) spent more time in unions with a pre-union child than male respondents in unions with a shorter LAT phase.

At the time of household formation, the men were on average two years older than the women. Interestingly, the age at which a household was formed does not seem to have been related to the 
length of the prior partnership. This suggests that the partnerships which lasted for several years before the partners moved in together were formed at younger ages than the partnerships with shorter partnership durations; this assumption is confirmed by the data. With regard to the partnership order, the sample demonstrates that the majority of the households were not formed with the first partner, but with partners of a higher order. However, the residential partnership studied was often the first union in the respondent's life course. This was more likely to have been the case if the partners had been together for several years before moving in together. The correlation between the order of the partnership and the residential union was found to be modest (estimations showed a correlation coefficient of 0.42 for the partnerships of the male respondents and of 0.44 for the partnerships of the female respondents, respectively).

The majority of the individuals with an LAT period of 26 months or more $\left(3^{\text {rd }}\right.$ tercile) had been living with their parents at the time the partnership started, while this living arrangement was less common among the respondents with a shorter partnership duration. The respondents who had spent several years dating their partner ( $3^{\text {rd }}$ tercile) were also more highly educated and were more likely to have been enrolled in education at the time the partnership was formed. In sum, these characteristics indicate that the long-term LAT couples were a special group consisting mainly of young people who did not have prior partnership experience, and who were not living independently when they fell in love with their partner. In some cases, the student lifestyle and the still-dominant parental influence may have kept these young adults from moving in together (Brien et al. 2006; Thornton et al. 1995). Finally, Catholic respondents were more prevalent among the group of longterm LAT couples $\left(3^{\text {rd }}\right.$ tercile).

Table 1 also reveals that the partnerships that were directly transformed into residential unions were a selected group. Both the women and the men in this category tended to be non-Christian church 
members and foreign-born, and they were more likely than others to have formed direct marriages and to have stepchildren. On the one hand, these characteristics suggest that these couples were more traditional; instead of prolonged dating, they committed to the partnership rather quickly. These traits may also suggest, however, that these couples defined the start of the partnership as the start of their joint life. The presence of stepchildren provides a practical reason for why the partners moved in together soon after the partnership started: when children live in the household of one of the partners, it becomes necessary to organize childcare if the partners want to meet outside of the household. Thus, the partners may have chosen to move in together quickly in order to simplify their relationship.

Table 1: Sample composition by gender and partnership duration prior to household formation (terciles), in column percent

\begin{tabular}{|c|c|c|c|c|c|c|c|c|}
\hline \multirow{2}{*}{$\begin{array}{l}\text { LAT length } \\
\text { Respondents } \\
\end{array}$} & \multicolumn{2}{|c|}{$\begin{array}{l}\text { Direct } \\
\text { household } \\
\text { formation: } 0 \\
\text { months }\end{array}$} & \multicolumn{2}{|c|}{$\begin{array}{l}\text { 1st tercile: } \\
\text { 1-9 months }\end{array}$} & \multicolumn{2}{|c|}{$\begin{array}{l}\text { 2nd tercile: } \\
\text { 10-25 months }\end{array}$} & \multicolumn{2}{|c|}{\begin{tabular}{|l|} 
3rd tercile: \\
26-120 months
\end{tabular}} \\
\hline & Male & Female & Male & Female & Male & Female & Male & Female \\
\hline \multicolumn{9}{|c|}{ Partnership characteristics } \\
\hline \multicolumn{9}{|l|}{ Parental status (TV) } \\
\hline No common child & 53 & 50 & 55 & 52 & 58 & 51 & 51 & 54 \\
\hline $\begin{array}{l}\text { Common child conceived/born } \\
\text { before hh formation }\end{array}$ & 6 & 7 & 9 & 11 & 10 & 15 & 17 & 9 \\
\hline $\begin{array}{l}\text { Common child conceived/born only } \\
\text { after hh formation }\end{array}$ & 41 & 43 & 36 & 37 & 32 & 34 & 32 & 37 \\
\hline \multicolumn{9}{|l|}{$\begin{array}{l}\text { Number and age of common } \\
\text { children (TV) }\end{array}$} \\
\hline No children & 53 & 50 & 56 & 52 & 54 & 51 & 57 & 54 \\
\hline 1 child, $<2$ years & 19 & 18 & 19 & 19 & 19 & 19 & 19 & 21 \\
\hline 1 older child & 10 & 9 & 9 & 9 & 9 & 9 & 8 & 7 \\
\hline 2 or more children, youngest & 14 & 16 & 11 & 14 & 14 & 15 & 12 & 13 \\
\hline$<2$ years & 5 & 6 & 4 & 6 & 5 & 7 & 4 & 4 \\
\hline \multicolumn{9}{|l|}{2 or more children, youngest older } \\
\hline Stepchildren in household (TC) & & & & & & & & \\
\hline No & 93 & 83 & 95 & 86 & 96 & 91 & 99 & 95 \\
\hline Yes & 7 & 17 & 5 & 14 & 4 & 3 & 1 & 5 \\
\hline \multicolumn{9}{|l|}{ Pre-union child (TC) } \\
\hline No & 94 & 94 & 92 & 90 & 86 & 86 & 90 & 91 \\
\hline Yes & 6 & 6 & 8 & 10 & 14 & 14 & 10 & 9 \\
\hline \multicolumn{9}{|l|}{ Marital status (TV) } \\
\hline Cohabiting & 47 & 46 & 53 & 49 & 49 & 50 & 49 & 47 \\
\hline Married (direct marriage) & 28 & 28 & 13 & 14 & 18 & 17 & 17 & 19 \\
\hline
\end{tabular}




\begin{tabular}{|c|c|c|c|c|c|c|c|c|}
\hline Married (marriage after cohabitation) & 25 & 26 & 34 & 37 & 32 & 33 & 34 & 34 \\
\hline \multicolumn{9}{|c|}{ Individual background characteristics } \\
\hline $\begin{array}{l}\text { Age when partnership was } \\
\text { formed (mean in years) (TC) }\end{array}$ & 25.8 & 23.3 & 25.2 & 23.4 & 24.3 & 22.7 & 21.6 & 19.8 \\
\hline $\begin{array}{l}\text { Partnership order }(\mathrm{TC}) \\
1^{\text {st }} \text { order } \\
\text { Higher order }\end{array}$ & $\begin{array}{l}44 \\
56\end{array}$ & $\begin{array}{l}40 \\
60\end{array}$ & $\begin{array}{l}35 \\
65\end{array}$ & $\begin{array}{l}32 \\
68\end{array}$ & $\begin{array}{l}39 \\
61\end{array}$ & $\begin{array}{l}39 \\
61\end{array}$ & $\begin{array}{l}51 \\
49\end{array}$ & $\begin{array}{l}55 \\
45\end{array}$ \\
\hline $\begin{array}{l}\text { Union order }(\mathrm{TC}) \\
1^{\text {st }} \text { order } \\
\text { Higher order }\end{array}$ & $\begin{array}{l}70 \\
30 \\
\end{array}$ & $\begin{array}{l}67 \\
33 \\
\end{array}$ & $\begin{array}{l}73 \\
27 \\
\end{array}$ & $\begin{array}{l}70 \\
30 \\
\end{array}$ & $\begin{array}{l}83 \\
17 \\
\end{array}$ & $\begin{array}{l}78 \\
22\end{array}$ & $\begin{array}{l}92 \\
8\end{array}$ & $\begin{array}{l}92 \\
8 \\
\end{array}$ \\
\hline $\begin{array}{l}\text { Lived with parents when } \\
\text { partnership was formed (TV) } \\
\text { Alone } \\
\text { With parents }\end{array}$ & $\begin{array}{l}66 \\
34 \\
\end{array}$ & $\begin{array}{l}64 \\
36 \\
\end{array}$ & $\begin{array}{l}64 \\
36 \\
\end{array}$ & $\begin{array}{l}63 \\
37 \\
\end{array}$ & $\begin{array}{l}55 \\
45 \\
\end{array}$ & $\begin{array}{l}55 \\
45 \\
\end{array}$ & $\begin{array}{l}43 \\
57 \\
\end{array}$ & $\begin{array}{l}40 \\
60 \\
\end{array}$ \\
\hline $\begin{array}{l}\text { School education }(\mathrm{TC}) \\
\text { Low } \\
\text { Middle } \\
\text { High } \\
\text { Missing } \\
\end{array}$ & $\begin{array}{c}30 \\
39 \\
30 \\
<1\end{array}$ & $\begin{array}{l}31 \\
42 \\
26 \\
<1 \\
\end{array}$ & $\begin{array}{l}27 \\
37 \\
35 \\
<1\end{array}$ & $\begin{array}{l}22 \\
44 \\
33 \\
1 \\
\end{array}$ & $\begin{array}{l}27 \\
35 \\
37 \\
<1 \\
\end{array}$ & $\begin{array}{l}19 \\
41 \\
39 \\
<1\end{array}$ & $\begin{array}{l}21 \\
33 \\
45 \\
<1 \\
\end{array}$ & $\begin{array}{l}14 \\
39 \\
46 \\
<1 \\
\end{array}$ \\
\hline $\begin{array}{l}\text { Enrolled in education when } \\
\text { partnership was formed (TC) } \\
\text { No } \\
\text { Yes }\end{array}$ & $\begin{array}{l}87 \\
13 \\
\end{array}$ & $\begin{array}{l}82 \\
18 \\
\end{array}$ & $\begin{array}{l}85 \\
15 \\
\end{array}$ & $\begin{array}{l}80 \\
20 \\
\end{array}$ & $\begin{array}{l}80 \\
20 \\
\end{array}$ & $\begin{array}{l}77 \\
23\end{array}$ & $\begin{array}{l}76 \\
24 \\
\end{array}$ & $\begin{array}{l}71 \\
29 \\
\end{array}$ \\
\hline $\begin{array}{l}\text { Church membership (TC) } \\
\text { Catholic } \\
\text { Protestant } \\
\text { None } \\
\text { Other } \\
\text { Missing } \\
\end{array}$ & $\begin{array}{l}25 \\
23 \\
32 \\
20 \\
<1\end{array}$ & $\begin{array}{l}22 \\
30 \\
30 \\
17 \\
<1\end{array}$ & $\begin{array}{l}27 \\
29 \\
35 \\
8 \\
<1\end{array}$ & $\begin{array}{l}27 \\
33 \\
32 \\
7 \\
<1\end{array}$ & $\begin{array}{l}30 \\
30 \\
30 \\
9 \\
<1\end{array}$ & $\begin{array}{l}29 \\
32 \\
30 \\
8 \\
<1\end{array}$ & $\begin{array}{l}36 \\
28 \\
26 \\
9 \\
<1\end{array}$ & $\begin{array}{l}37 \\
32 \\
23 \\
8 \\
<1\end{array}$ \\
\hline $\begin{array}{l}\text { Birth cohorts (TC) } \\
1971-1973 \\
1981-1983\end{array}$ & $\begin{array}{l}72 \\
28 \\
\end{array}$ & $\begin{array}{l}64 \\
36 \\
\end{array}$ & $\begin{array}{l}64 \\
36 \\
\end{array}$ & $\begin{array}{l}63 \\
37 \\
\end{array}$ & $\begin{array}{l}63 \\
37 \\
\end{array}$ & $\begin{array}{l}64 \\
36 \\
\end{array}$ & $\begin{array}{l}62 \\
38 \\
\end{array}$ & $\begin{array}{l}60 \\
40 \\
\end{array}$ \\
\hline $\begin{array}{l}\text { Birth place (TC) } \\
\text { West G. } \\
\text { East G. } \\
\text { Elsewhere }\end{array}$ & $\begin{array}{l}55 \\
19 \\
26\end{array}$ & $\begin{array}{l}51 \\
18 \\
31\end{array}$ & $\begin{array}{l}64 \\
21 \\
15\end{array}$ & $\begin{array}{l}61 \\
21 \\
18\end{array}$ & $\begin{array}{l}66 \\
18 \\
15\end{array}$ & $\begin{array}{l}66 \\
18 \\
16\end{array}$ & $\begin{array}{l}70 \\
17 \\
13\end{array}$ & $\begin{array}{l}70 \\
17 \\
13\end{array}$ \\
\hline $\begin{array}{l}\text { Lived with both parents until age } \\
18 \text { (TC) } \\
\text { Yes } \\
\text { No } \\
\text { Missing } \\
\end{array}$ & $\begin{array}{l}47 \\
19 \\
34 \\
\end{array}$ & $\begin{array}{l}51 \\
25 \\
24 \\
\end{array}$ & $\begin{array}{l}50 \\
20 \\
30 \\
\end{array}$ & $\begin{array}{l}48 \\
24 \\
28 \\
\end{array}$ & $\begin{array}{l}58 \\
15 \\
27 \\
\end{array}$ & $\begin{array}{l}57 \\
18 \\
25 \\
\end{array}$ & $\begin{array}{l}60 \\
11 \\
29 \\
\end{array}$ & $\begin{array}{l}59 \\
14 \\
27 \\
\end{array}$ \\
\hline $\begin{array}{l}\text { Employment status (TV) } \\
\text { Non-empl. } \\
\text { Employed } \\
\text { No inform. }\end{array}$ & $\begin{array}{l}7 \\
37 \\
56\end{array}$ & $\begin{array}{l}18 \\
31 \\
50\end{array}$ & $\begin{array}{l}8 \\
48 \\
44\end{array}$ & $\begin{array}{l}19 \\
33 \\
49\end{array}$ & $\begin{array}{l}8 \\
49 \\
43\end{array}$ & $\begin{array}{l}17 \\
33 \\
50\end{array}$ & $\begin{array}{l}6 \\
55 \\
39\end{array}$ & $\begin{array}{l}16 \\
36 \\
48\end{array}$ \\
\hline Sample size & 404 & 528 & 1,089 & 1,444 & 960 & 1,351 & 1,007 & 1,447 \\
\hline Events & 106 & 163 & 361 & 468 & 263 & 378 & 200 & 310 \\
\hline
\end{tabular}

Source: German family panel (pairfam/DemoDiff), Release 3.0 (2011/2012)

Notes: Weighted sample

TC: Time-constant information (presented in mean values or in column percent, respectively) 
TV: Time-varying information (presented as relative exposure time in percent of total person months (column percents))

\subsection{Multivariate results}

Table 2 gives the multivariate regressions by gender. The results are shown in relative risks. In a first step, I estimated a basic model (Model 1), which included the baseline (time since household formation), the central covariate of interest (partnership duration prior household formation), and control covariates which accounted for the special data structure of the German Family Panel (birth cohort design, oversampling of eastern Germans). Model 2 included other control covariates (religion, education, living with both parents, age at partnership formation, partnership order, presence of stepchildren, marital and employment status). It further controls for the parental status of the union, distinguishing between being childless and having a common child conceived prior to or after household formation. Model 3 additionally accounts for the children's ages. Figure 3 shows the results of an interaction of the marital status with the length of the LAT period prior to household formation.

\section{LAT length and union stability}

The results in Model 1 to 3 show that whether the couple progressed to household formation quickly or slowly had a significant impact on the stability of the union. The association between LAT length and household dissolution remained statistically significant when other individual and partnership characteristics were controlled for. Compared to the $2^{\text {nd }}$ tercile, the risk of dissolution was significantly higher among those who moved in together during the first nine months of the partnership ( $1^{\text {st }}$ tercile), and it was lower among the couples who spent several years dating before

forming a household ( $3^{\text {rd }}$ tercile). The length of the LAT phase was clearly negatively linked to the 
risk of union dissolution. These findings lend support to the main research hypothesis, which states that a long LAT phase should improve the partners' knowledge of each other's characteristics, and should therefore increase stability. The unions without a prior LAT phase did not, however, fit in this picture: compared to the unions with a short LAT period $\left(1^{\text {st }}\right.$ tercile), the partnerships which started as residential unions had a somewhat lower risk of union dissolution. This suggests that the couples who had formed a household directly represent a special group.

\section{Family status and union stability}

From Model 2 it can be seen that the couples who already had common children at the time of household formation had a significantly higher risk of breaking up than the couples who formed a family after they had moved in together. The risk of dissolution was highest among the couples without common children. This most likely shows that the couples with pre-union children had not had enough time to evaluate each other's characteristics. Model 3 reveals that having several children or one child under age two reduced the risk of union dissolution if the children were not already present at the time the household was formed. Having a single child above the age of two reduced the disruption risk only among the unions reported by the male respondents, while the risk was not different from being childless among the unions reported by the female respondents. Living in a stepfamily had a different impact on union stability depending on whether the respondents were male or female. Women who were living with their own or their partner's children from previous relationships had an increased risk of union dissolution, while men experienced significantly higher levels of union stability when they formed a stepfamily. It is likely that the differences between men and women in the recall of stepfamily episodes produced this finding, as Martin and colleagues (2011) have argued. According to official statistics (Statistisches Bundesamt 2012), the majority of children live with their mother after their parents separate, which means that stepfamilies often consist of a biological mother and a non-biological father. If this partnership splits up, the mother 
will continue to live with her children, while the children's contact with the stepfather might stop. This suggests that the male respondents may be more likely to underreport the presence of stepchildren. As a consequence, the stability of the unions with stepchildren among the male respondents would have been overestimated in the analysis. ${ }^{7}$

\section{Other factors associated with union stability}

Among both the male and the female respondents, marriage was found to strongly promote union stability. The direct marriages had a risk of union dissolution that was similar to that of the marriages preceded by cohabitation. Most of the results of the other control covariates were in line with previous findings. The partnerships formed by the respondents of the birth cohorts 1981-1983 had a higher risk of household dissolution than the partnerships formed by the men and women born in 1971-1973. This might be related to the fact that the partnership histories of the people in the younger cohorts were censored earlier. Thus, early and probably more unstable partnerships were over-represented. The disruption risk among the female respondents in eastern Germany turned out to be lower than that of their counterparts in western Germany, once the control covariates were added. Separate estimations indicated that this decomposition effect was attributable to the religious background (results not shown). Women who were not religious had an elevated risk of experiencing household disruption. Non-affiliated individuals were over-represented in eastern Germany (Schnor 2012). Controlling for the separation-proneness of religiously unaffiliated persons thus affected the coefficients on birth place. This relationship was found only among the female respondents, which suggests that religious background played a more important role among the women. The unions of the respondents who had not been living with both parents until they

\footnotetext{
${ }^{7}$ This is indeed confirmed by model estimations which considered the stepfamily constellation. These results showed that among the unions reported by the male respondents, the stepfather families had significant lower relative risks of separation $(0.23$ ( $\mathrm{p}<0.01))$ than the unions without stepchildren (ref.). The stepmother families faced higher risks (1.63 (n. s.)). Among the female respondents, however, the stepfather families had significantly higher relative risks of separation $(1.26$ ( $\mathrm{p}<0.05)$, as did the stepmother families $(1.33$ (n. s.)).
} 
reached adulthood were less stable, as were the unions of the male respondents who had been living with their parents at the time the partnership was formed. Women with low levels of education or episodes of non-employment had an increased risk of union dissolution.

Table 2: Relative risks from a piecewise constant survival model of household dissolution within eight years after household formation among German men and women born 1971-1973 and 1981-1983

\begin{tabular}{|c|c|c|c|c|c|c|}
\hline \multirow[b]{2}{*}{ Respondent } & \multicolumn{2}{|c|}{ Model 1} & \multicolumn{2}{|c|}{ Model 2} & \multicolumn{2}{|c|}{ Model 3} \\
\hline & Male & Female & Male & Female & Male & Female \\
\hline $\begin{array}{l}\text { Partnership duration prior household } \\
\text { formation } \\
\text { Direct household formation } \\
\text { 1st quintile (1-9 months) } \\
\text { 2nd quintile (10-25 months) } \\
\text { 3rd quintile (26-120 months) }\end{array}$ & $\begin{array}{l}1.02 \\
1.26^{* * *} \\
1 \\
0.71^{* * *}\end{array}$ & $\begin{array}{l}1.13 \\
1.19^{* *} \\
1 \\
0.76^{* * *}\end{array}$ & $\begin{array}{l}1.00 \\
1.27^{* *} \\
1 \\
0.66^{* * *}\end{array}$ & $\begin{array}{l}1.09 \\
1.14^{*} \\
1 \\
0.81^{* * *}\end{array}$ & $\begin{array}{l}1.00 \\
1.25^{* *} \\
1 \\
0.66^{* * *}\end{array}$ & $\begin{array}{l}1.09 \\
1.15^{*} \\
1 \\
0.81^{* * *}\end{array}$ \\
\hline $\begin{array}{l}\text { Baseline (time since household formation) } \\
\text { (TV) } \\
0-1 \text { years } \\
\text { 1-2 years } \\
\text { 2-3 years } \\
\text { 3-5 years } \\
\text { 5-8 years }\end{array}$ & $\begin{array}{l}0.91 \\
1 \\
1.03 \\
0.86 \\
0.63^{* * *}\end{array}$ & $\begin{array}{l}0.79^{* *} \\
1 \\
1.07 \\
0.95 \\
0.68^{* * *}\end{array}$ & $\begin{array}{l}0.79^{* *} \\
1 \\
1.22^{*} \\
1.34^{* *} \\
1.48^{* * *}\end{array}$ & $\begin{array}{l}0.69^{* * *} \\
1 \\
1.24^{* *} \\
1.36^{* * *} \\
1.32^{* * *}\end{array}$ & $\begin{array}{l}0.79^{* *} \\
1 \\
1.20^{*} \\
1.27^{* *} \\
1.31^{*}\end{array}$ & $\begin{array}{l}0.69^{* * *} \\
1 \\
1.22^{* *} \\
1.30^{* * *} \\
1.23^{*}\end{array}$ \\
\hline $\begin{array}{l}\text { Residential union order } \\
1^{\text {st }} \text { order } \\
\text { Higher order }\end{array}$ & $\begin{array}{l}1 \\
1.00\end{array}$ & $\begin{array}{l}1 \\
1.12\end{array}$ & $\begin{array}{l}1 \\
1.16\end{array}$ & $\begin{array}{l}1 \\
1.12\end{array}$ & $\begin{array}{l}1 \\
1.20\end{array}$ & $\begin{array}{l}1 \\
1.14\end{array}$ \\
\hline $\begin{array}{l}\text { Birth cohorts } \\
1971-1973 \\
1981-1983 \\
\end{array}$ & $\begin{array}{l}1 \\
1.89 * * *\end{array}$ & $\begin{array}{l}1 \\
1.49 * * *\end{array}$ & $\begin{array}{l}1 \\
1.36^{* * *}\end{array}$ & $\begin{array}{l}1 \\
1.25^{* * *}\end{array}$ & $\begin{array}{l}1 \\
1.36 * * *\end{array}$ & $\begin{array}{l}1 \\
1.26^{* * *}\end{array}$ \\
\hline $\begin{array}{l}\text { Birth place } \\
\text { West G. } \\
\text { East G. } \\
\text { Elsewhere }\end{array}$ & $\begin{array}{l}1 \\
1.03 \\
0.44^{* * *}\end{array}$ & $\begin{array}{l}1 \\
0.95 \\
0.56 * * *\end{array}$ & $\begin{array}{l}1 \\
0.95 \\
0.76^{*}\end{array}$ & $\begin{array}{l}1 \\
0.68 * * * \\
0.85\end{array}$ & $\begin{array}{l}1 \\
0.94 \\
0.76^{*}\end{array}$ & $\begin{array}{l}1 \\
0.67 * * * \\
0.84^{*}\end{array}$ \\
\hline $\begin{array}{l}\text { Stepfamily } \\
\text { No } \\
\text { yes }\end{array}$ & & & $\begin{array}{l}1 \\
0.46^{* * *}\end{array}$ & $\begin{array}{l}1 \\
1.20^{*}\end{array}$ & $\begin{array}{l}1 \\
0.45^{* * *}\end{array}$ & $\begin{array}{l}1 \\
1.27^{* *}\end{array}$ \\
\hline $\begin{array}{l}\text { Parental status (TV) } \\
\text { No common child } \\
\text { Common child conceived/born before hh } \\
\text { formation } \\
\text { Common child conceived/born only after hh } \\
\text { formation }\end{array}$ & & & $\begin{array}{l}3.21 * * * \\
1.90^{* * *} \\
1\end{array}$ & $\begin{array}{l}2.02^{* * *} \\
1.47^{* * *} \\
1\end{array}$ & & \\
\hline $\begin{array}{l}\text { Pre-union Child } \\
\text { No } \\
\text { Yes }\end{array}$ & & & & & $\begin{array}{l}1 \\
1.63 * * *\end{array}$ & $\begin{array}{l}1 \\
1.31 * *\end{array}$ \\
\hline $\begin{array}{l}\text { Number and ages of common children } \\
\text { (TV) } \\
\text { No children } \\
1 \text { child, }<2 \text { years } \\
1 \text { older child }\end{array}$ & & & & & $\begin{array}{l}1 \\
0.27 * * * \\
0.57 * * *\end{array}$ & $\begin{array}{l}1 \\
0.48^{* * *} \\
0.84\end{array}$ \\
\hline
\end{tabular}




\begin{tabular}{|c|c|c|c|c|c|c|}
\hline $\begin{array}{l}2 \text { or more children, youngest }<2 \text { years } \\
2 \text { or more children, youngest older }\end{array}$ & & & & & $\begin{array}{l}0.18^{* * *} \\
0.52^{* * *}\end{array}$ & $\begin{array}{l}0.26^{* * *} \\
0.68^{* * *}\end{array}$ \\
\hline $\begin{array}{l}\text { Marital status (TV) } \\
\text { Cohabiting } \\
\text { Married (direct marriage) } \\
\text { Married (marriage after cohabitation) }\end{array}$ & & & $\begin{array}{l}1 \\
0.29 * * * \\
0.29 * * *\end{array}$ & $\begin{array}{l}1 \\
0.47^{* * *} \\
0.32^{* * *}\end{array}$ & $\begin{array}{l}1 \\
0.30^{* * *} \\
0.30^{* * *}\end{array}$ & $\begin{array}{l}1 \\
0.50^{* * *} \\
0.34^{* * *}\end{array}$ \\
\hline $\begin{array}{l}\text { Church membership } \\
\text { Catholic } \\
\text { Protestant } \\
\text { None } \\
\text { Other } \\
\text { Missing }\end{array}$ & & & $\begin{array}{l}1.16 \\
1 \\
1.16 \\
1.17 \\
1.05\end{array}$ & $\begin{array}{l}0.92 \\
1 \\
1.40^{* * *} \\
0.70^{* *} \\
0.92\end{array}$ & $\begin{array}{l}1.16 \\
1 \\
1.15 \\
1.18 \\
1.02\end{array}$ & $\begin{array}{l}0.92 \\
1 \\
1.39 * * * \\
0.72^{* *} \\
0.78\end{array}$ \\
\hline $\begin{array}{l}\text { School education } \\
\text { Low } \\
\text { Middle } \\
\text { High } \\
\text { Missing } \\
\end{array}$ & & & $\begin{array}{l}1.12 \\
1 \\
1.06 \\
0.86 \\
\end{array}$ & $\begin{array}{l}1.17^{*} \\
1 \\
1.02 \\
1.53 \\
\end{array}$ & $\begin{array}{l}1.13 \\
1 \\
1.06 \\
0.95 \\
\end{array}$ & $\begin{array}{l}1.17^{*} \\
1 \\
1.03 \\
1.58^{*}\end{array}$ \\
\hline $\begin{array}{l}\text { Enrolled in education when partnership } \\
\text { was formed } \\
\text { No } \\
\text { Yes }\end{array}$ & & & $\begin{array}{l}1 \\
1.12\end{array}$ & $\begin{array}{l}1 \\
0.90\end{array}$ & $\begin{array}{l}1 \\
1.13\end{array}$ & $\begin{array}{l}1 \\
0.89\end{array}$ \\
\hline $\begin{array}{l}\text { Lived with both parents until age } 18 \\
\text { Yes } \\
\text { No } \\
\text { Missing }\end{array}$ & & & $\begin{array}{l}1 \\
1.32^{* * *} \\
1.23^{*}\end{array}$ & $\begin{array}{l}1 \\
1.47^{* * *} \\
1.09\end{array}$ & $\begin{array}{l}1 \\
1.32^{* * *} \\
1.23^{*}\end{array}$ & $\begin{array}{l}1 \\
1.44^{* * *} \\
1.07\end{array}$ \\
\hline $\begin{array}{l}\text { Lived with parents when partnership was } \\
\text { formed } \\
\text { No } \\
\text { Yes }\end{array}$ & & & $\begin{array}{l}1 \\
1.14\end{array}$ & $\begin{array}{l}1 \\
1.07\end{array}$ & $\begin{array}{l}1 \\
1.15\end{array}$ & $\begin{array}{l}1 \\
1.06\end{array}$ \\
\hline $\begin{array}{l}\text { Age when partnership was formed } \\
14-19 \text { years } \\
20-23 \text { years } \\
24-28 \text { years } \\
29-38 \text { years }\end{array}$ & & & $\begin{array}{l}1.12 \\
1 \\
0.87 \\
0.78^{*}\end{array}$ & $\begin{array}{l}1.13^{*} \\
1 \\
0.88 \\
0.78^{*}\end{array}$ & $\begin{array}{l}1.12 \\
1 \\
0.88 \\
0.79 *\end{array}$ & $\begin{array}{l}1.13^{*} \\
1 \\
0.90 \\
0.77 *\end{array}$ \\
\hline $\begin{array}{l}\text { Partnership order } \\
\text { 1st order } \\
\text { Higher order }\end{array}$ & & & $\begin{array}{l}1 \\
1.16\end{array}$ & $\begin{array}{l}1 \\
1.14\end{array}$ & $\begin{array}{l}1 \\
1.15^{*}\end{array}$ & $\begin{array}{l}1 \\
1.13^{*}\end{array}$ \\
\hline $\begin{array}{l}\text { Employment status (TV) } \\
\text { Non-employed } \\
\text { Employed } \\
\text { Missing }\end{array}$ & & & $\begin{array}{l}1.17 \\
1 \\
0.96\end{array}$ & $\begin{array}{l}1.18^{* *} \\
1 \\
1.03\end{array}$ & $\begin{array}{l}1.17 \\
1 \\
0.95 \\
\end{array}$ & $\begin{array}{l}1.20^{* *} \\
1 \\
1.03\end{array}$ \\
\hline $\mathbf{N}$ (unions) $=$ & 3460 & 4770 & 3460 & 4770 & 3460 & 4770 \\
\hline $\mathbf{N}$ (respondents) $=$ & 2888 & 3864 & 2888 & 3864 & 2888 & 3864 \\
\hline $\mathbf{N}$ (union dissolutions) $=$ & 930 & 1319 & 930 & 1319 & 930 & 1319 \\
\hline
\end{tabular}

Source: German family panel (pairfam/DemoDiff), Release 3.0 (2011/2012)

Notes: All models include a person-specific random intercept;

Significance levels: ${ }^{* * *} \mathrm{p}<0.01 ;{ }^{* *} \mathrm{p}<0.05$; $^{*} \mathrm{p}<0.1$.

TV = time-varying covariate (on monthly base) 


\section{Marital status, LAT length and union stability}

Figure 3 shows the effect of the length of the LAT period on the risk of union dissolution, depending on whether the couple was married or cohabiting. The direct marriages and the converted marriages were grouped into a single category because of sample size issues and because the multivariate results in Table 2 suggested that their risks of union dissolution were very similar. The results are shown in standardized relative risks with 95 percent confidence intervals.

Among the non-marital and the marital unions, the risk of union dissolution decreased with the length of the non-residential partnership episode if the unions without any LAT period were disregarded. It was hypothesized that this effect should be stronger among the non-marital cohabitations than among the marriages. The empirical results could not clearly confirm this assumption; they rather suggest that the effect of the LAT period does not depend on the marital status of the union.

Compared to the reference category (unions with a LAT length of 10 to 25 months), a short LAT length $\left(1^{\text {st }}\right.$ tercile) had a significant impact on the stability of the cohabitations, but not on the marriages. Similar amounts of person-time were spent in cohabitation and in marriage, and the LAT categories had similar sizes. However, there were far fewer union dissolutions among the marriages. Thus, the range of the 95 percent confidence intervals was larger among the latter group. Based on the directions of the effects, the results suggest that a short LAT period decreased union stability among the marriages as well. The unions in which the non-residential period exceeded 25 months were more stable than the unions with shorter LAT periods. These results were significant different compared to the reference category only among both the marital and the non-marital unions reported by the male respondents; however, the results from the female respondents pointed in the 
same direction. Control covariates like religious affiliation did not produce these differentials; the interaction terms in a model without control covariates (equivalent to Model 1) showed the same pattern.

Figure 3 does not provide clear results regarding the relative risk of union dissolution for the couples with no prior period of living apart together. Except in the case of the marriages reported by the female respondents, the partnerships which directly started as residential unions had a higher degree of union stability than the unions with a prior LAT period of one to nine months. However, the range of the 95 percent confidence intervals was quite wide. It is difficult to determine why the marital unions without a prior LAT period had significantly higher levels of instability only among the unions reported by the female respondents. This finding may indicate that the data did not rely on the same unions. Partnership histories reported by male respondents are often assumed to be less reliable than those reported by women, possibly because men have more problems remembering the correct dates of marriage and household formation. ${ }^{8}$ In this case, I would not be comparing the same kind of unions. It is also possible that women are more likely than men to assign the same date to the partnership formation, the household formation, and the marriage if the union was dissolved. The stability of the unions with direct household formation would be then be underestimated. It should also be noted that the women and the men belonged to the same birth cohorts, but were different ages when the household was formed. The analysis followed the unions in their first eight years; thus, the cut-off point may have been different for the male and the female respondents.

\footnotetext{
${ }^{8}$ Identical dates of marriage and household formation may be an indication of recall difficulties. More of the men (43 percent) than the women ( 34 percent) who were married at the time they moved in their partner reported that the marriage formation date and the household formation date were identical.
} 

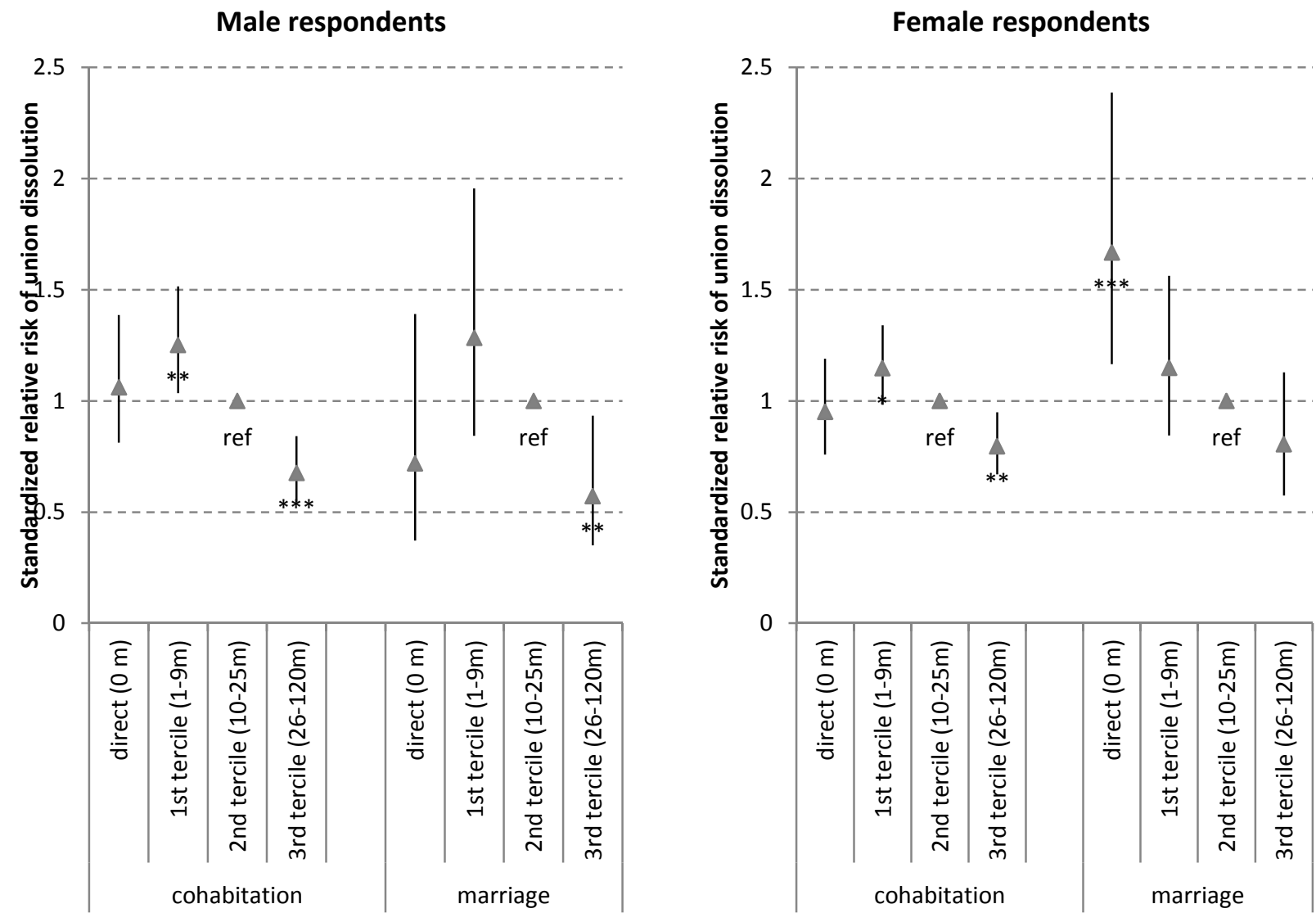

Figure 3: Transition to union dissolution; results of an interaction of marital status and LAT length, shown in standardized relative risks (within each union context, unions with a short LAT length (1-9 months) present the reference category)

Source: German family panel (pairfam/DemoDiff), Release 3.0 (2011/2012)

Notes:

To standardize the relative risks, I estimated an interaction model (separately for male and female respondents) taking cohabiting unions with a LAT length of 10 to 25 months ( $2^{\text {nd }}$ tercile) as the reference category. The results for marital unions were divided by the coefficient of the marital unions with a LAT length of 10 to 25 months ( $2^{\text {nd }}$ tercile). I then estimated the interaction model again taking these unions as the reference category to obtain the significance levels for the relative risks of marital unions. 
Both models included a person-specific random intercept and controlled for the baseline, birth cohort and birth place, union and partnership order, church membership, school education, educational enrollment, age and living arrangement at the time the partnership was formed, residence with both parents until $18^{\text {th }}$ birthday, presence of stepchildren and presence and ages of common children, and employment status.

Significance levels: ${ }^{* * *} \mathrm{p}<0.01 ;{ }^{* *} \mathrm{p}<0.05{ }^{*} \mathrm{p}<0.1$; $^{\mathrm{p}}<0.15$

\section{Conclusion - Does waiting pay off?}

This study examined the effects of partnership duration prior to household formation on union stability. A number of previous studies have focused on the antecedents of union stability. However, the influence of the LAT period has rarely been examined. This seems surprising because most partners lived in separate households before they moved in together: this study revealed that around 90 percent of the unions formed by men and women born in 1971-1973 and in 1981-1983 were preceded by some period of living apart together, and that 50 percent of the residential unions were formed within the first partnership year, which confirmed the findings of previous research (Schneider \& Rüger 2008). While one might expect that the LAT period would have had a stabilizing influence on union stability, it was also conceivable that it would have had a destabilizing influence. The economic theory of the family (Becker 1991; Becker et al. 1977; Oppenheimer 1988) stressed the importance of couples knowing each other's attributes. Couples should experience higher levels of union stability if they had sufficient time to collect information about the partner before they invested in the partnership through household formation. The competing hypothesis referred to arguments prevalent in exchange theory (Thibaut \& Kelley 1958), and stated that the LAT length 
should negatively affect union stability because it indicates that the couple hesitated in investing in the partnership.

The empirical results showed that the risk of household dissolution declines with the amount of time spent in a partnership prior to household formation. The risk of union disruption was higher if the couple had a short (one to nine months) non-residential partnership period before the joint household was formed. Couples who spent 10 to 25 months living apart together had better union prospects. The chances of union survival were highest if the union belonged to the group of longterm LAT couples ( $>26$ months). It seems that the information argument prevails with regard to partnership duration. While keeping their separate residences, a couple can spend their day-to-day life together in a "trial union" that allows them to evaluate each other's characteristics. Several traits can be readily assessed after the first meeting (e.g., education, religion, family background, race, appearance). During the courtship process, traits that are more difficult to assess, such as honesty, reliability, and personality, can be evaluated(Oppenheimer 1988). The LAT period functions as a testing stage that enables individuals not only to select the appropriate partner, but also to adapt to each other in daily life, and to formulate common strategies. The shorter the LAT period, the more likely it is that partnership difficulties will emerge after household formation. Thus, a long LAT period did not appear to have been associated with a low interaction density, which would have been reflected in higher rates of union disruption after moving in together. It instead showed that the couple were very well matched because the low barriers to separation favored a strong weeding-out of potential mismatches. If the couple overcame the obstacles to household formation after a long period of time, they were more likely to have enjoyed a high level of relationship stability after moving in together. Unlike the premarital cohabitation phase, a longer LAT phase was not shown to have increased the risk of union dissolution. It is possible that an optimal time frame exists only with regard to premarital cohabitation, with those who rush to marriage having an increased chance of 
mismatch, and those who waited quite a while before marrying having reasonable doubts about the success of the marriage.

The couples who spent more than 25 months in separate residences before moving in together were often Catholic, started their partnership at a young age, did not have prior partnership experiences, and were not living independently when the partnership was formed. The living conditions at the time the partnership was formed — such as being enrolled in education or living with their parentswere not found to have influenced the stability of unions after the household was formed. Having a higher level of education or a religious background tended to increase the stability of the union, but it did not explain why unions with a long LAT period showed the highest stability levels. This clearly demonstrates that the period of living apart together had an independent influence on union stability which could not be explained by individual characteristics.

The partnerships that had no LAT period represented a special case. According to the main hypothesis, these unions should have been more fragile than the unions with an LAT length of one to nine months. However, the results revealed that they were more stable. This may be related to a recall problem: the respondents who reported entering cohabitation directly may have in fact had a prior LAT period which they did not remember. However, this finding may also show that these partners were highly committed: i.e., that they decided to directly start their partnership in the more committed form of a residential union instead of in the less committed form of LAT, maybe because they were strongly convinced that their partnership would last.

Fourteen percent of the unions with an LAT length of 10 to 25 months had conceived a child prior to household formation. Pre-union conceptions were less common among the unions with an LAT length of more than 25 months. This might indicate that the pregnancy was not planned. The anticipated arrival of the child might have shortened the LAT period among the parents-to-be 
because the formation of a joint household offered several practical advantages: the parents could share childcare tasks, they could spend less money due to the economies of scale of having a single household, and they could easily meet in their free time. After household formation, however, these couples experienced a higher risk of union disruption than the couples who conceived their children during the residential period. These results provide additional support for the first hypothesis: waiting pays off with regard to household formation, as well as with regard to family formation.

The multivariate results revealed that the cohabiting unions had much lower levels of union stability than the marital unions. The LAT length was positively associated with union stability in both of the union forms. It was assumed that the length of the LAT period would have affected the cohabitations more than the marriages. Previous studies have shown that the partnership duration prior to household formation reduced the risk of separation among marriages (e.g., Brüderl et al. 1999; Brüderl \& Kalter 2001). This study has provided some evidence that the effect is similar on cohabitations as it is on marriages. This leads to suggest that the same mechanisms drive the stability of non-marital and marital residential unions: not having enough time to test the partner prior to household formation has negative consequences for marital and non-marital union stability; while taking the time to get to know, test, and weed out incompatible partners adds to the stability of marriages and cohabitations. Due to the limited sample size, these conclusions remain rather tentative. Future studies are needed to shed more light on the effect the LAT period has on the stability of cohabitations in comparison to the effect it has on marriages.

This study provided new insight into the topic of union stability, and contributed to understanding the non-residential partnership phase. The results showed that waiting pays off for couples, as the length of the partnership period prior to household formation had a significant influence on the union dissolution risk. However, the empirical analyses could not disentangle the exact mechanisms 
that explain the positive relationship between the length of the LAT period and subsequent union stability. The theoretical literature suggests that personality traits should be more relevant than sociodemographic characteristics in explaining the transition to household formation. This issue was not addressed because individual information on both partners was lacking. While it was assumed that the weeding-out process played a central role, this aspect was not modeled in the empirical part of this research. Future studies may include the decision to form a household as a process in the modeling.

In the private life courses of many individuals, the dates of partnership, residential, and marital episodes are often far apart. This study demonstrates that empirical research on separation needs to pay more attention to the appropriate definition of the events of interest. In the past, researchers switched their focus from marriage to the period of co-residence: several decades ago, scholars (e.g., Becker et al. 1977; Morgan \& Rindfuss 1985; Teachman 1982; Teachman \& Polonko 1990) agreed to define the date of marital dissolution as the date the couple stopped living together rather than as the legal end of a marriage, because it is a "more realistic marker of the end of a marital union" (Bracher et al. 1992: 405). These studies focused exclusively on the partnership stability of marriages. In more recent studies, researchers also considered non-marital residential episodes in their analyses and analyzed the union stability of marriages and cohabitations. This study has shown that one needs to look further and consider the non-residential partnership episode as an integral part of the partnership. The date of partnership formation represents a more realistic marker of the start of a partnership than the date when the couple moved in together. It was also shown that the date of separation and the date of moving out of the joint household often differ. This makes it necessary to clarify the event of interest. In the present study, the focus was on residential unions. Household dissolution was defined as the dependent variable. The detailed partnership information included in the German Family Panel made it possible to distinguish the dates of partnership formation and 
household formation, as well as the dates of separation and household dissolution. Fortunately, a growing number of surveys gather detailed partnership information. In the future, the distinction between partnership formation and household formation in the data should be less of a concern.

In recent decades, new forms of private living arrangements, such as cohabitation and nonresidential partnerships, have become common in many societies. However, the fact that LAT partnerships have become more widespread should not necessarily lead concerns being raised that partnerships in general are becoming more fragile. Rather, a long non-residential partnership episode helps to increase union stability. Waiting — not rushing-pays off. 


\section{References}

Amato, P.R. (1996). Explaining the Intergenerational Transmission of Divorce. Journal of Marriage and the Family, 58(2): 628-640.

Asendorpf, J. B. (2008). Living apart together: Alters-und Kohortenabhängigkeit einer heterogenen Lebensform [Engl.: Living apart together. Age and cohort dependency of a heterogeneous living arrangement]. KZfSS Kölner Zeitschrift für Soziologie und Sozialpsychologie, 60(4): 749-764.

Becker, G.S., Landes, E.M., Michael, R.T. (1977). An economic analysis of marital stability. The Journal of Political Economy, 85: 1141-1187.

Becker, G.S. (1991). A Treatise on the Family, Enlarged Edition. Cambridge, Mass.: Harvard University Print.

Bennett, N.G., Blanc, A.K., \& Bloom, D.E. (1988). Commitment and the Modern Union: Assessing the Link Between Premarital Cohabitation and Subsequent Marital Stability. American Sociological Review, 53(1): 127-138.

Berrington, A., \& Diamond, I. (1999). Marital Dissolution among the 1958 British birth cohort: The role of cohabitation. Population Studies, 53(1): 19-38.

Blossfeld, H.-P., Klijzing, E., Pohl, K,, Rohwer (1999). Why do cohabiting couples marry? An example of a causal event history approach to interdependent systems. Quality and Quantity, 33: $229-242$. 
Bracher, M., Santow, G., Morgan, S.P., Trussell, J. (1993). Marriage Dissolution in Australia: Models and Explanations. Population Studies, 47 (3): 403-425.

Brien, M.J., Lillard, L.A., Stern, S. (2006). Cohabitation, Marriage, and Divorce in a Model of Match Quality. International Economic Review, 47(2): 451-494.

Brown, S.L. (2003). Relationship Quality Dynamics of Cohabiting Unions. Journal of Family Issues, 24(5): 583-601.

Brüderl, J., Diekmann, A., Engelhardt, H. (1999). Artefakte in der Scheidungsursachenforschung? Eine Erwiderung auf einen Artikel von Yasemin Niephaus [Engl.: Artifacts in the causes of divorce research? A reply to an article by Yasemin Niephaus]. Kölner Zeitschrift für Soziologie und Sozialpsychologie, 51: 744-753.

Brüderl, J., \& Kalter, F. (2001). The dissolution of marriages: The role of information and maritalspecific capital. Journal of Mathematical Sociology, 25(4): 403-421.

Brüderl, J., Diekmann, A., Engelhardt, H. (1997). Erhöht eine Probeehe das Scheidungsrisiko? [Engl.: Does a trial marriage increase the risk of divorce?]. Kölner Zeitschrift für Soziologie und Sorialpsychologie, 49: 205-222.

Carmichael, G. A. (1995). Consensual partnering in the more developed countries. Journal of the Australian Population Association, 12(1): 51-86.

Castro-Martín, T., Domínguez-Folgueras, M., \& Martín-García, T. (2008). Not truly partnerless: Non-residential partnerships and retreat from marriage in Spain. Demographic Research, 18(16): 443468. 
Cherlin, A., \& McCarthy, J. (1984). Demographic Analysis of Family and Household Structures.

Final Report Contract No 1.HD.12802, National Institute for Child Health and Human

Development.

Dex, S. (1995). The Reliability of Recall Data: a Literature Review. Bulletin de Méthodologie Sociologique, 49: 58-89.

Duncan, S., \& Phillips, M. (2011). People who live apart together (LATs): new family form or just a stage?. International Review of Sociology, 21(3): 513-532.

Engelhardt, H. (2002). Zur Dynamik von Ehescheidungen. Theoretische und empirische Analysen [Engl.: On the dynamics of divorce. Theoretical and empirical analyses]. Berlin: Duncker \& Humboldt.

Ermisch, J., \& Siedler, T. (2008). Living Apart Together. In: Brynin, M., Ermisch, J. (eds.), Changing relationships, New York: Taylor \& Francis: 29-43.

Gutierrez, R. G. (2002). Parametric frailty and shared frailty survival models. Stata Journal, 2(1): 2244.

Guzzo, K.B. (2009). Marital Intentions and the Stability of First Cohabitations. Journal of Family Issues, 30(2): 179-205.

Hoem, J. M. (1989). Limitations of a heterogeneity technique: selectivity issues in conjugal union disruption at parity zero in contemporary Sweden. Stockholm Research Reports in Demography No. 56.

Hoem, B., \& Hoem, J. (1992). The disruption of marital and non-marital unions in contemporary Sweden. In: Trussel, J., Hankinson, R., Tilton, J. (eds.), Demographic applications of event history analysis. Oxford: Clarendon Press: 61-93. 
Huinink, J., Brüderl, J., Nauck, B., Walper, S., Castiglioni, L., Feldhaus, M. (2010). Panel Analysis of intimate relationships and family dynamics (pairfam): Conceptual framework and design. Arbeitspapier des Beziehungs- und Familienpanels, No.17.

Jalovaara, M. (2013). Socioeconomic resources and the dissolution of cohabitations and marriages. European Journal of Population, 29 (2): 167-193.

Klijzing, E. (1992). 'Weeding'in the Netherlands: first-union disruption among men and women born between 1928 and 1965. European Sociological Review, 8(1): 53-70.

Köppen, K. (2011). Marriage and Cohabitation in western Germany and France (Doctoral dissertation, Rostock, Univ., Diss., 2011).

Kreyenfeld, M., Walke, R., Salzburger, V., Schnor. C., Bastin, S., \& Kuhnt, A.-K (2011). DemoDiff Wave 1: Supplement to the pairfam Data Manual. MPIDR Technical Report 2011-004, Rostock: Max Planck Institute for Demographic Research.

Kreyenfeld, M., Goldstein, J., Walke, R., Trappe, H., Huinink, J. (2013a): Demographic Differences in Life Course Dynamics in Eastern and Western Germany (DemoDiff). GESIS Datenarchiv, Köln. ZA5684 Datenfile Version 3.0.0, doi:10.4232/demodiff.5684.3.0.0

Kreyenfeld, M., Walke, R., Salzburger, V., Lenke,R., Hensel, T. \& Mir Mousavi, B. (2013b): DemoDiff Supplement to the pairfam Data Manual (Release 3.0). Max Planck Institute for Demographic Research, Rostock.

Kulu H., \& Boyle P.J. (2009). Premarital cohabitation and divorce: support fort the 'trial marriage' theory? Demographic Research, 23(31): 879-904. 
Le Bourdais, C., Neill, G., Vachon, N. (2000). Family disruption in Canada: Impact of the changing patterns of family formation and of female employment. Canadian Studies in Population, 27: 85-105.

Lesthaeghe, R., Meekers, D. (1986). Value changes and the dimensions of familialism in the European community. European Journal of Population, 2: 11-33.

Lesthaeghe, R., Surkyn, J., (1988). Cultural dynamics and economic theories of fertility change. Population and Development Review, 14: 1-45.

Lesthaeghe, R. (2010). The unfolding story of the second demographic transition. Population and Development Review, 36: 1-14.

Levin, I. (2004). Living Apart Together: A New Family Form. Current Sociology, 52(2): 223-240.

Levin, I., \& Trost, J. (1999). Living apart together. Community, work \& family, 2(3): 279-294.

Liu, G. (2002). How premarital children and childbearing in current marriage influence divorce of Swedish women in their first marriages. Demographic Research, 7: 389-406.

Lehrer, E.L. (2004). Religion as a Determinant of Economic and Demographic Behavior in the United States. Population and Development Review, 30: 707-726.

Lillard, L.A., Brien M.J., Waite L.J. (1995). Premarital cohabitation and subsequent marital dissolution: a matter of self-selection? Demography, 32: 437-457.

Lyngstad, T.H., \& Jalovaara, M. (2010). A review of antecendents of union dissolution. Demographic Research, 23: 257-292. 
Manlove, J., Wildsmith, E., Ikramullah, E., Ryan, S., Holcombe, E., Scott, M., Peterson, K. (2012). Union Transitions Following the Birth of a Child to Cohabiting Parents. Population Research and Policy Review, 31: 361-386.

Manning, W.D. (2001). Childbearing in Cohabiting Unions: Racial and Ethnic Differences. Family Planning Perspectives, 33(5): 217-223

Martin, V., Le Bourdais, C., \& Lapierre-Adamcyk, É. (2011). Stepfamily instability in Canada-The impact of family composition and union type. Zeitschrift für Familienforschung-Journal of Family Research, 23(2): 196-218.

Morgan, S.P., \& Rindfuss, R. (1985). Marital Disruption: Structural and Temporal Dimensions. American Journal of Sociology, 90: 1055-1077.

Murphy, M. J. (1985). Demographic and Socio-economic Influences on Recent British Marital Breakdown Patterns. Population studies, 39 (3): 441-460.

Nauck, B., Brüderl, J., Huinink, J., Walper, S. (2012). Beziehungs- und Familienpanel (pairfam). GESIS Datenarchiv, Köln. ZA5678 Datenfile Version 3.0.0, doi:10.4232/pairfam.5678.3.0.0.

Niephaus, Y. (1999). Der Einfluss vorehelichen Zusammenlebens auf die Ehestabilität als methodisches Artefakt? [Engl.: The impact of premarital cohabitation to marriage stability as a methodological artifact?]. Kölner Zeitschrift für Soziologie und Sozialpsychologie, 51: 124-139.

Oláh, L. Sz. (2001). Gender and family stability: Dissolution of the first parental union in Sweden and Hungary. Demographic Research, 4: 29-96.

Oppenheimer, V.K. (1988). A Theory of Marriage Timing. American Journal of Sociology, 94: 563-591. 
Perelli-Harris, B., \& Sánchez Gassen, N.E. (2012). How similar are cohabitation and marriage? The spectrum of legal approaches to cohabitation across Western Europe. Population and Development Review, 38: 435-467.

Poortman, A.-R., \& Lyngstad, T. H. (2007). Dissolution risks in first and higher order marital and cohabiting unions. Social Science Research, 36: 1431-1446.

Poortman, A.-R., \& Liefbroer, A. C. (2010). Single's relational attitudes in a time of individualization. Social Science Research, 39: 938-949.

Raley, R.K. (2001). Increasing fertility in cohabiting unions: Evidence for the second demographic transition in the United States? Demography, 38: 59-66.

Regnier-Loilier, A., Beaujouan, É., \& Villeneuve-Gokalp, C. (2009). Neither single, nor in a couple. A study of living apart together in France. Demographic research, 21(4): 75-108.

Reimer, M. (2005). Autobiographisches Gedächtnis und retrospektive Datenerbebung: Die Rekonstruktion und Validität von Lebensverläufen (Doctoral Dissertation at the Free University Berlin). Max Planck Institute for Human Development.

Rindenfuss, R.R., \& VandenHeuvel, A. (1990). Cohabitation: A Precursor to Marriage or an Alternative to Being Single? Population and Development Review, 16(4): 703-726.

Rhoades, G.K., Stanley, S.M., Markman, H.J. (2010). Should I Stay or Should I GO? Predicting Dating Relationship Stability From Four Aspects of Commitment. Journal of Family Psychology, 24(5): 543-550. 
Rhoades, G.K., Stanley, S.M., Markman, H.J. (2012). The Impact of the Transition to Cohabitation on Relationship Functioning: Cross-Sectional and Longitudinal Findings. Journal of Family Pyschology, 26(3): 348-358.

Schneider, N. F., \& Rüger, H. (2008). Beziehungserfahrungen und Partnerschaftsverläufe vor der Heirat. Eine empirische Analyse von Angehörigen der Eheschließungskohorte 1999-2005 [Engl.: Experiences with relationships and the course of the premarital partnership. An empirical analysis of members of the 1999-2005 marriage cohort in Germany]. Zeitschrift für Familienforschung-Journal of Family Research, 20(2): 131-156.

Schnor, C. (2012). Trennungsrisiko von Paaren mit Kindern: Der Einfluss der Religion in West-und Ostdeutschland [Engl:: Separation risks of couples with children: The influence of religion in Western and Eastern Germany]. Zeitschrift für Familienforschung-Journal of Family Research-Sonderheft. 229-256.

Schnor, C., \& Bastin, S. (forthcoming). Partners and Babies. Partnership and Fertility Histories of the German Family Panel (pairfam/DemoDiff, waves 1-3) as an Event History Data Set. Forthcoming as a pairfam Technical Report.

Sobotka, T., \& Toulemon, L. (2008). Overview Chapter 4: Changing family and partnership behaviour: Common trends and persistent diversity across Europe. Demographic Research, Special Collection 7: 85-138.

Statistisches Bundesamt (2012): Bevölkerung und Erwerbstätigkeit. Haushalte und Familien, Ergebnisse des Mikrozensus. Fachserie 1, Reihe 3, Wiesbaden.

Steele, F., Joshi, H., Kallis, C., Goldstein, H. (2006). Changing compatibility of cohabitation and childbearing between young British women born in 1958 and 1970. Population Studies, 60: 137-152. 
Svarer, M. (2004). Is your love in vain? Another look at premarital cohabitation and divorce. Journal of Human Ressources, 39: 523-535.

Teachman, J.D. (1982). Methodological Issues in the Analysis of Family Formation and Dissolution. Journal of Marriage and the Family, 44: 1037-1053.

Teachman, J.D., Thomas, J., Paasch, K. (1991). Legal Status and the Stability of Residential unions. Demography, 28(4): 571-586.

Teachman, J. D., \& Polonko, K. A. (1990). Cohabitation and marital stability in the United States. Social Forces, 69(1): 207-220.

Teachman, J.D. (2002). Stability across cohorts in divorce risk factors. Demography, 39(2): 331-352.

Thibaut, J. W., \& Kelley, H. H. (1959). The social psychology of groups. New York: John Wiley \& Sons, Inc.

Thomson, E., \& Colella, U. (1992). Cohabitation and Marital Stability - Quality or Commitment. Journal of Marriage and the Family, 54(2): 259-267.

Thornton, A., Axinn, W. G., \& Teachman, J. D. (1995). The influence of school enrollment and accumulation on cohabitation and marriage in early adulthood. American Sociological Review, 762774.

Van de Kaa, D.J. (1987). Europe’s second demographic transition. Population Bulletin, 42: 1-59.

White, L.K. (1990). Determinants of Divorce - a Review of Research in the 80s. Journal of Marriage and the Family, 52(4): 904-912. 
Wu, Z. (1995). The Stability of Cohabiting Relationships: The Role of Children. Journal of Marriage and the Family, 57: 231-236. 


\section{Appendix}

\subsection{Figures}

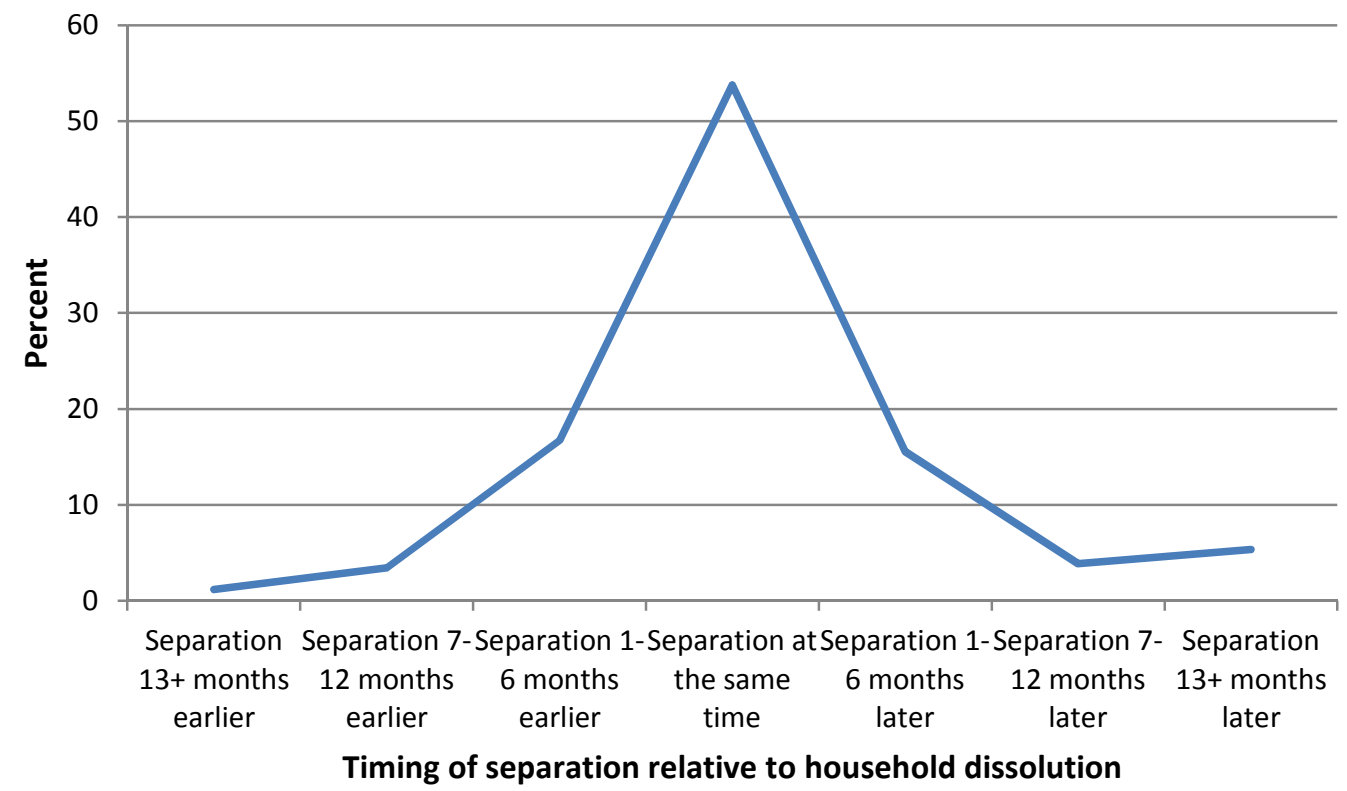

Figure 4: Timing of separation relative to household dissolution (= dependent variable) among partnerships in which household dissolution occurred within the first eight years of co-residence $(\mathrm{N}=2,249)$

Source: German family panel (pairfam/DemoDiff), Release 3.0 (2011/2012)

Note: Weighted sample 


\subsection{Robustness checks}

Several sensitivity checks were conducted to test whether the results concerning the determining influence of the LAT length on union stability were robust to changes in the sample (see Table 3, Table 4 and Figure 5 in Appendix). In check I, partnerships which started during the teenage years were dropped, because they might differ from partnerships formed in adulthood. Check II excluded unions whose LAT length exceeded five years. Check III considered the total union episode gathered in the German Family Panel without censoring after eight years. In check IV the analysis was restricted to first unions. Separate models for the older and the younger birth cohorts were estimated in check V. These modifications did not change the model results, but the coefficients lost significance in the sample that included only respondents born in 1981 to 1983; this is likely attributable to the sample size.

In Table 2, the multivariate results in Model 2 showed that the risk of union dissolution decreased after the first year of household formation. It could be argued that a long dating period increases union stability, because the couple enters the analysis at a later point, when the baseline risk is already lower (Teachman \& Polonko 1990). Engelhardt 2002, Niephaus 1999). This argument was tested in two ways. First, the union duration (baseline) was interacted with the length of the LAT period, which can reveal whether the baseline was shifted to the left among unions with longer dating duration (Figure 5). Second, I estimated a model in which the baseline date was shifted by the length of the LAT phase, and treated couples with a prior LAT period as left-truncated cases (Check VI). However, these checks did not provide additional explanation. The sample statistics revealed that the unions with differing LAT phases spent similar amounts of time in marriage and with children. A plausible explanation for this finding is that with household formation a new "clock" 
starts, and thus the risk of union dissolution does not clearly continue the separation trend observed for the time while not living together.

When only higher order unions were considered (Check VII), the results revealed different relative risks for unions of different LAT lengths; e.g., the risk of union disruption among the couples who directly formed a household was significantly higher than the risk of the couples in the $2^{\text {nd }}$ tercile, which had always functioned as the reference category. Accounting for the faster transition to household formation among higher-order unions, the results were similar to those for first unions.
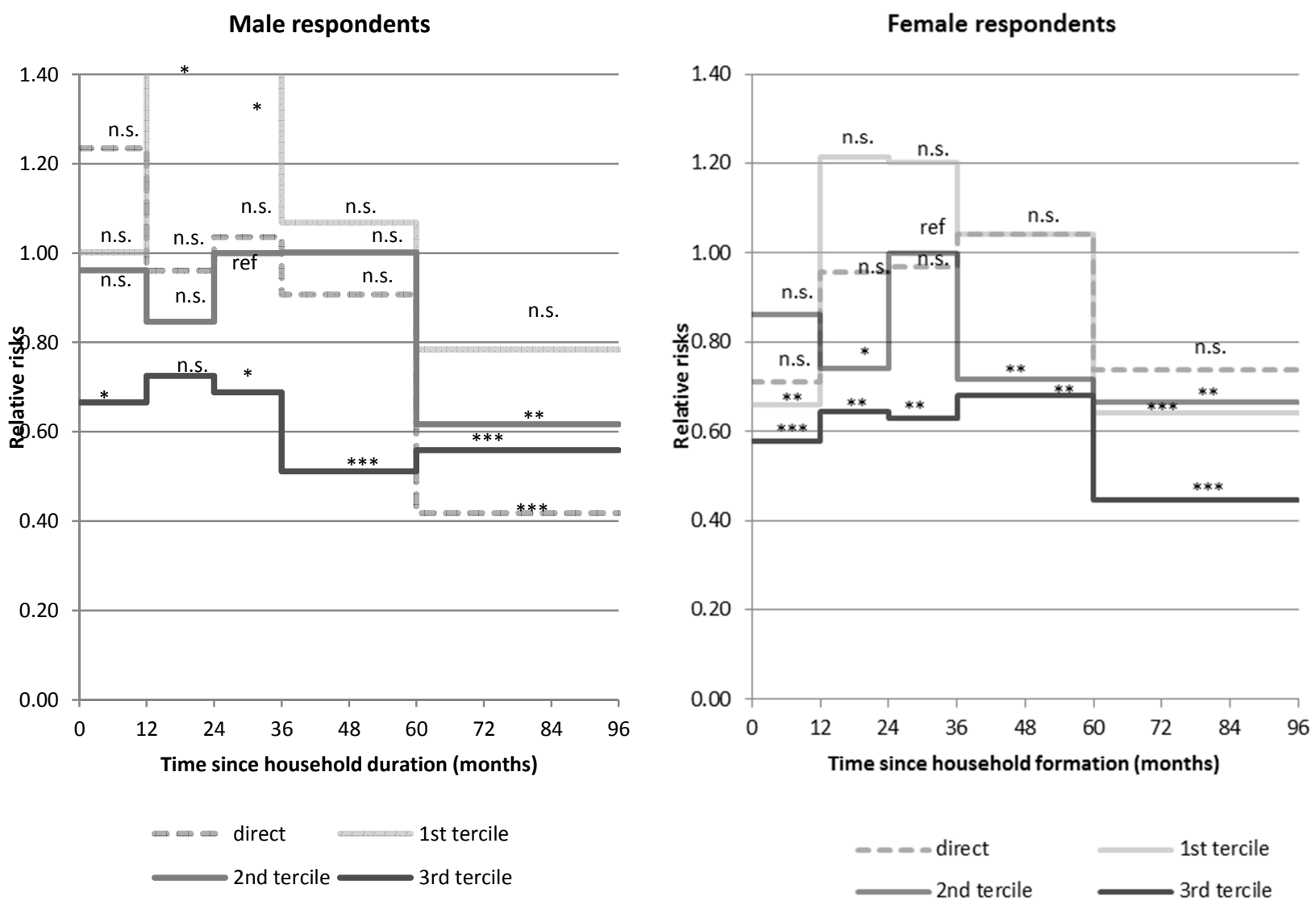
Figure 5: Robustness check VII: Interaction of the baseline with the dating length, results shown in relative risks.

Source: German family panel (pairfam/DemoDiff), Release 3.0 (2011/2012)

Notes:

Both models included a person-specific random intercept and controlled for birth cohort and birth place, union order.

Significance levels: ${ }^{* * *} \mathrm{p}<0.01 ; * * \mathrm{p}<0.05 ; * \mathrm{p}<0.1$. 


\begin{tabular}{|c|c|c|c|c|c|c|c|}
\hline & Check I & Check II & $\begin{array}{l}\text { Check } \\
\text { III }\end{array}$ & Check IV & Check V & & Check VI \\
\hline & $\begin{array}{l}\text { Sample: } \\
\text { only those } \\
\text { who were } \\
\text { age } 18+ \\
\text { when } \\
\text { partnershi } \\
\text { p was } \\
\text { formed }\end{array}$ & $\begin{array}{l}\text { Sample: } \\
\text { Only } \\
\text { unions } \\
\text { with } \\
\text { maximum } \\
\text { dating } \\
\text { length of } \\
5 \text { years }\end{array}$ & $\begin{array}{l}\text { Without } \\
\text { censoring } \\
\text { after } 8 \\
\text { years } \\
\text { (last } \\
\text { observed } \\
\text { exit at } 282 \\
\text { months) }\end{array}$ & $\begin{array}{l}\text { Sample: } \\
\text { only first } \\
\text { unions }\end{array}$ & $\begin{array}{l}\text { Sample: } \\
\text { only birth } \\
\text { cohorts } \\
1971- \\
1973\end{array}$ & $\begin{array}{l}\text { Sample: } \\
\text { only birth } \\
\text { cohorts } \\
1981-1983\end{array}$ & $\begin{array}{l}\text { Dating } \\
\text { length } \\
\text { considere } \\
\mathrm{d} \text { as part } \\
\text { of } \\
\text { baseline; } \\
\text { Sample: } \\
\text { only first } \\
\text { unions; } \\
\text { Without } \\
\text { censoring } \\
\text { after } 8 \\
\text { years }\end{array}$ \\
\hline \multicolumn{8}{|c|}{ Unions reported by male respondents } \\
\hline Direct: $0 \mathrm{~m}$ & 1.01 & 1.01 & 1.05 & 0.84 & 1.14 & 0.76 & 0.86 \\
\hline $1^{\text {st }}$ tercile: $1-9 \mathrm{~m}$ & $1.26 * *$ & $1.26^{* *}$ & $1.26^{* * *}$ & $1.18^{*}$ & $1.29 * *$ & 1.24 & $1.21 * *$ \\
\hline $2^{\text {nd }}$ tercile: $10-25 \mathrm{~m}$ & 1 & 1 & 1 & 1 & 1 & 1 & 1 \\
\hline $\begin{array}{l}3^{\text {rd }} \text { tercile: } 26- \\
120 \mathrm{~m}\end{array}$ & $0.66^{* * *}$ & $0.71 * * *$ & $0.65^{* * *}$ & $0.64 * * *$ & $0.75^{* *}$ & $0.55^{* * *}$ & $0.63^{* * *}$ \\
\hline \multicolumn{8}{|c|}{ Unions reported by female respondents } \\
\hline Direct: $0 \mathrm{~m}$ & 1.16 & 1.08 & 1.14 & 0.90 & 1.13 & 1.02 & 0.98 \\
\hline $1^{\text {st }}$ tercile: $1-9 \mathrm{~m}$ & $1.18^{*}$ & $1.14^{* *}$ & $1.13^{*}$ & $1.19^{* *}$ & 1.14 & 1.14 & $1.16^{* *}$ \\
\hline $2^{\text {nd }}$ tercile: $10-25 \mathrm{~m}$ & 1 & 1 & 1 & 1 & 1 & 1 & 1 \\
\hline $\begin{array}{l}3^{\text {rd }} \text { tercile: } 26- \\
120 \mathrm{~m}\end{array}$ & $0.81 * *$ & $0.85^{* *}$ & $0.77 * * *$ & $0.83 * *$ & $0.72^{* * *}$ & 0.91 & $0.78^{* * *}$ \\
\hline
\end{tabular}

Source: German family panel (pairfam/DemoDiff), Release $3.0(2011 / 2012)$

Notes: All models included a person-specific random intercept and controlled for birth cohort and birth

place, union and partnership order, church membership, school education, educational enrollment, age and

living arrangement at the time the partnership was formed, residence with both parents until $18^{\text {th }}$ birthday,

presence of stepchildren and presence and ages of common children, employment status, marital status.

Significance levels: ${ }^{* * *} \mathrm{p}<0.01 ; * * \mathrm{p}<0.05 ;{ }^{*} \mathrm{p}<0.1$. 
Table 4: Robustness check VIII

\begin{tabular}{|c|c|c|}
\hline Check VIII & & \\
\hline Sample: only higher-order unions & & \\
\hline & Unions reported by male respondents & $\begin{array}{c}\text { Unions reported by female } \\
\text { respondents }\end{array}$ \\
\hline Direct household formation & $1.85^{* *}$ & $1.47 * *$ \\
\hline original $1^{\text {st }}$ tercile: $1-9$ months & $1.66^{* *}$ & 1.02 \\
\hline original $2^{\text {nd }}$ tercile: $10-25$ months & 1 & 1 \\
\hline original $3^{\text {rd }}$ tercile: $26-120$ months & 0.95 & $0.62^{*}$ \\
\hline Direct household formation & 1.13 & $1.40^{* *}$ \\
\hline adapted 1 st tercile: $1-5$ months & 1.19 & 0.98 \\
\hline adapted $2^{\text {nd }}$ tercile: $6-14$ months & 1 & 1 \\
\hline adapted $3^{\text {rd }}$ tercile: $15-120$ months & $0.59 * *$ & 0.78 \\
\hline
\end{tabular}

Source: German family panel (pairfam/DemoDiff), Release 3.0 (2011/2012)

Notes: All models included a person-specific random intercept and controlled for birth cohort and birth

place, union and partnership order, church membership, school education, educational enrollment, age and

living arrangement at the time the partnership was formed, residence with both parents until $18^{\text {th }}$ birthday, presence of stepchildren and presence and ages of common children, employment status, marital status.

Significance levels: ${ }^{* * *} \mathrm{p}<0.01 ;{ }^{* *} \mathrm{p}<0.05 ;{ }^{*} \mathrm{p}<0.1$. 